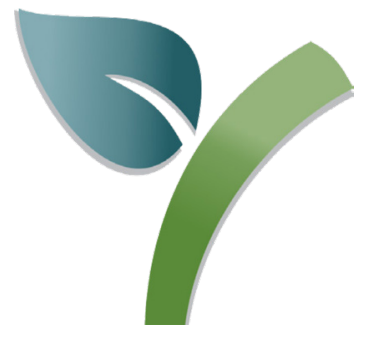

\title{
VIROSES EM TRIGO NO BRASIL: UMA VISÃO HISTÓRICA
}

\author{
Lucas Antonio Stempkowski ${ }^{1}$, Talita Bernardon Mar ${ }^{2}$, Fernando Sartori \\ Pereira $^{3}$, Ana Karoliny Alves Santos ${ }^{3}$, Juliana Borba Valente ${ }^{3}$, Douglas \\ Lau $^{2}$, Ricardo Trezzi Casa ${ }^{3}$, Fábio Nascimento da Silva ${ }^{3}$
}

\section{WHEAT VIRUSES IN BRAZIL: A HISTORICAL VIEW}

\begin{abstract}
RESUMO
O trigo foi introduzido no Brasil com a chegada dos colonizadores europeus. Por muito tempo, foi cultivado em menor escala, até que nos anos 1960-1970 mudanças na conjuntura econômica-tecnológica resultaram em um significativo aumento de sua área cultivada. Nesse período também houve um aumento da importância de vários problemas fitossanitários. As décadas de 1960-1970 marcam os primeiros registros científicos de descrição de vírus como patógenos dessa cultura no país. A história do conhecimento sobre viroses que infectam trigo no Brasil tem como elementos importantes: (i) as mudanças nos sistemas de produção e da paisagem agrícola; (ii) as novas tecnologias e ferramentas para estudo de vírus; e (iii) as introduções de vírus e seus vetores em território nacional.

PALAVRAS-CHAVE: Barley yellow dwarf virus, Luteoviridae, Wheat stripe mosaic virus, Benyviridae, Wheat streak mosaic virus, Potyviridae, Brazilian wheat spike virus, Tenuivirus
\end{abstract}

\begin{abstract}
Wheat was introduced in Brazil with the arrival of European settlers. For a long time, it was cultivated on a smaller scale until, in the 1960s-1970s, changes in the economic-technological situation resulted in a significant increase in the cultivated area. During this period, there was also an increase in the importance of several phytosanitary problems. The 1960s-1970s mark the first scientific records describing viruses as pathogens of this culture in the country. The history of knowledge about viruses in wheat in Brazil has as important elements: (i) changes in the production systems and in the agricultural landscape; (ii) new technologies and tools for the study of viruses; and (iii) introductions of viruses and their vectors in the national territory.

KEYWORDS: Barley yellow dwarf virus, Luteoviridae, Wheat stripe mosaic virus, Benyviridae, Wheat streak mosaic virus, Potyviridae, Brazilian wheat spike virus, Tenuivirus
\end{abstract}

\section{INTRODUÇÃO}

\section{A CULTURA DO TRIGO}

O trigo (Triticum spp.) é uma planta de ciclo anual que pertence à família Poaceae. Três espécies do gênero Triticum, T. aestivum L., T. monococcum L. e T. durum L., são cultivadas, sendo a primeira, a espécie de maior importância econômica. O trigo é considerado um alimento básico para a civilização, e sua trajetória segue paralelamente à história da humanidade, sendo uma das primeiras espécies de plantas domesticadas pelo homem. O grão do trigo é processado em farinha, que pode ser consumida

${ }^{1}$ Departamento de Fitopatologia/BIOAGRO, Universidade Federal de Viçosa, Viçosa, MG, 36570-900, Brazil. ${ }^{2}$ Embrapa Trigo, Passo Fundo, RS, 99050-970, Brazil. ${ }^{3}$ Programa de Pós-Graduação em Produção Vegetal, Universidade do Estado de Santa Catarina, Centro de Ciências Agroveterinárias, Lages, SC 88520-000. Autor para correspondência: Lucas Antonio Stempkowski (lucas.stempkowski@ ufv.br) 
na forma de pães, massas, bolos e biscoitos. Quando não atinge o padrão de qualidade para o consumo humano, o grão pode ser utilizado na fabricação de ração animal. A planta pode ser utilizada para pastejo e produção de silagem para animais (BRAMMER et al. 2011; CUNHA et al. 2011; FONTANELI et al. 2011).

A importância do trigo, desde os primórdios da humanidade, reflete nas estatísticas até os dias atuais. Entre os cereais mais cultivados e produzidos no mundo, o trigo ocupa a terceira posição, ficando atrás apenas do milho (Zea mays L.) e do arroz (Oryza spp.). A área atual de cultivo mundial de trigo corresponde a cerca de 216,5 milhões de hectares. Os países que mais produzem trigo localizam-se no hemisfério norte, incluindo China, Índia, Rússia, Estados Unidos e Canadá (Figura 1), e os maiores exportadores são Rússia, Estados Unidos, Canadá, Ucrânia e Austrália. Países como Egito, Indonésia, Argélia, Japão e o Brasil são os maiores importadores mundiais desse cereal (USDA 2021).

\section{O TRIGO NO BRASIL}

Os primeiros relatos de cultivos de trigo no Brasil são de 1534, inicialmente cultivado na capitania de São Vicente. No entanto, a cultura só adquiriu importância econômica no Brasil colonial a partir do século XVII, quando cultivado nos estados do Rio Grande do Sul e São Paulo (ROSSI \& NEVES 2004). O cultivo do trigo é uma prática de importância na composição de sistemas agrícolas sustentáveis de produção, sendo uma opção importante para a rotação e sucessão de culturas em sistemas de produção de grãos (DE MORI 2016). A produção nacional é de cerca de 5,4 milhões de toneladas de grãos em uma área pouco maior que 2 milhões de hectares, com um rendimento médio de aproximadamente 2.700 kg.ha-1 ${ }^{-1}$ A Região Sul é responsável por quase $90 \%$ da produção nacional, com destaque para os estados do Paraná e Rio Grande do Sul, principais produtores brasileiros (CONAB 2021) (Figura 2). O Brasil não é autossuficiente na produção de trigo, sendo que no país se produz menos de $50 \%$ do consumo interno, gerando a necessidade de importação do cereal (CONAB 2021). A triticultura nacional tem potencial para ofertar a quantidade necessária ao abastecimento, porém, fatores como custo de produção elevado, adequação da qualidade ao uso final, oscilações meteorológicas, fragilidades das relações e da coordenação no complexo agroindustrial e aspectos de política internacional afetam a competitividade do trigo brasileiro (DE MORI 2015).

O trigo brasileiro é cultivado em diferentes biomas e climas, o que tem reflexo nas principais doenças e pragas por região (LAU et al. 2011; LAU et al. 2020). As regiões tritícolas são classificadas em quatro (Figura 2).

A região 1 tem o inverno (época de cultivo do trigo) frio e úmido. A região 2 , moderadamente quente e úmida, tem temperaturas médias um

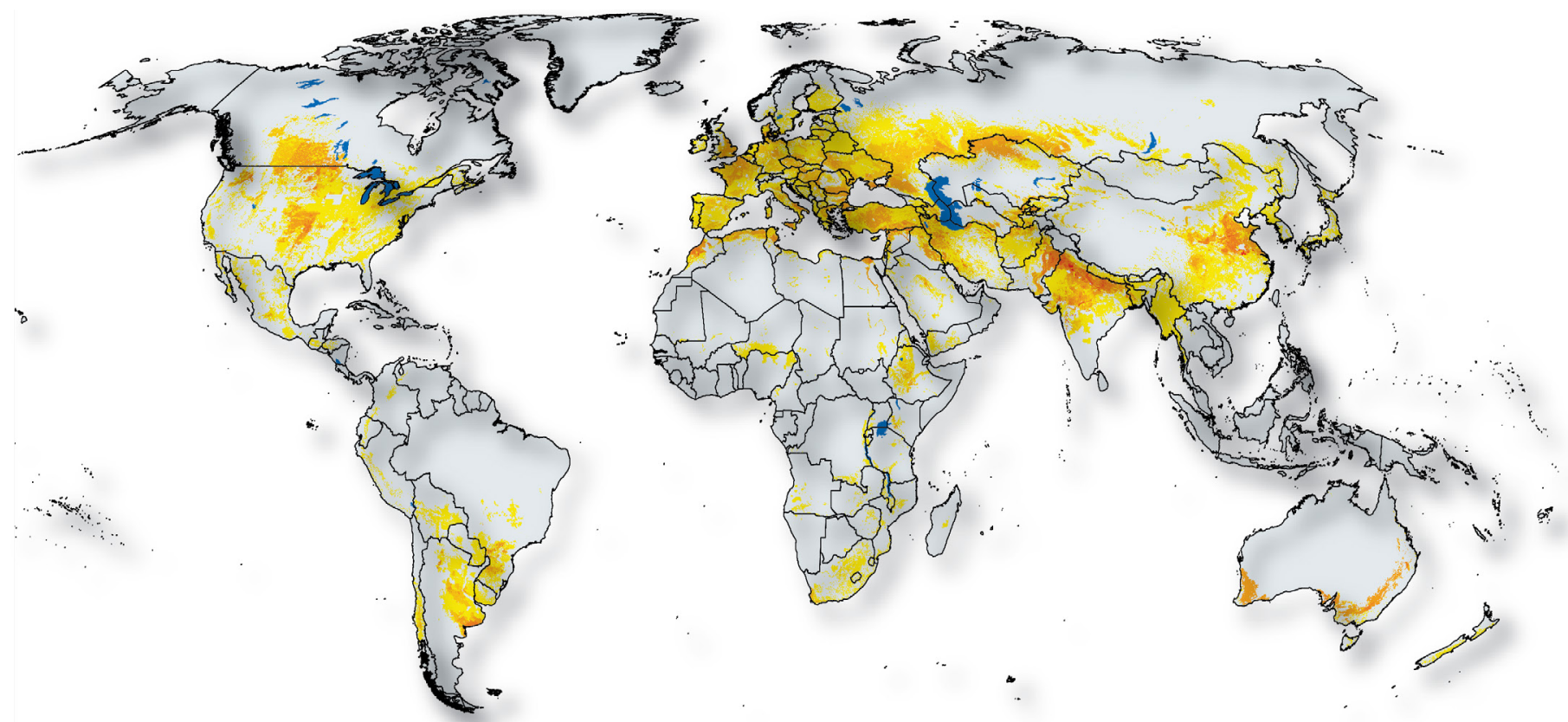

Figura 1. Regiões produtoras de trigo. Cores mais escuras indicam áreas nas quais o trigo é mais cultivado. Mapa obtido de You, L., U. Wood-Sichra, S. Fritz, Z. Guo, L. See, and J. Koo. 2014. Spatial Production Allocation Model (SPAM), 2005 Beta Version, from IFPRI (Harvest Choice). 


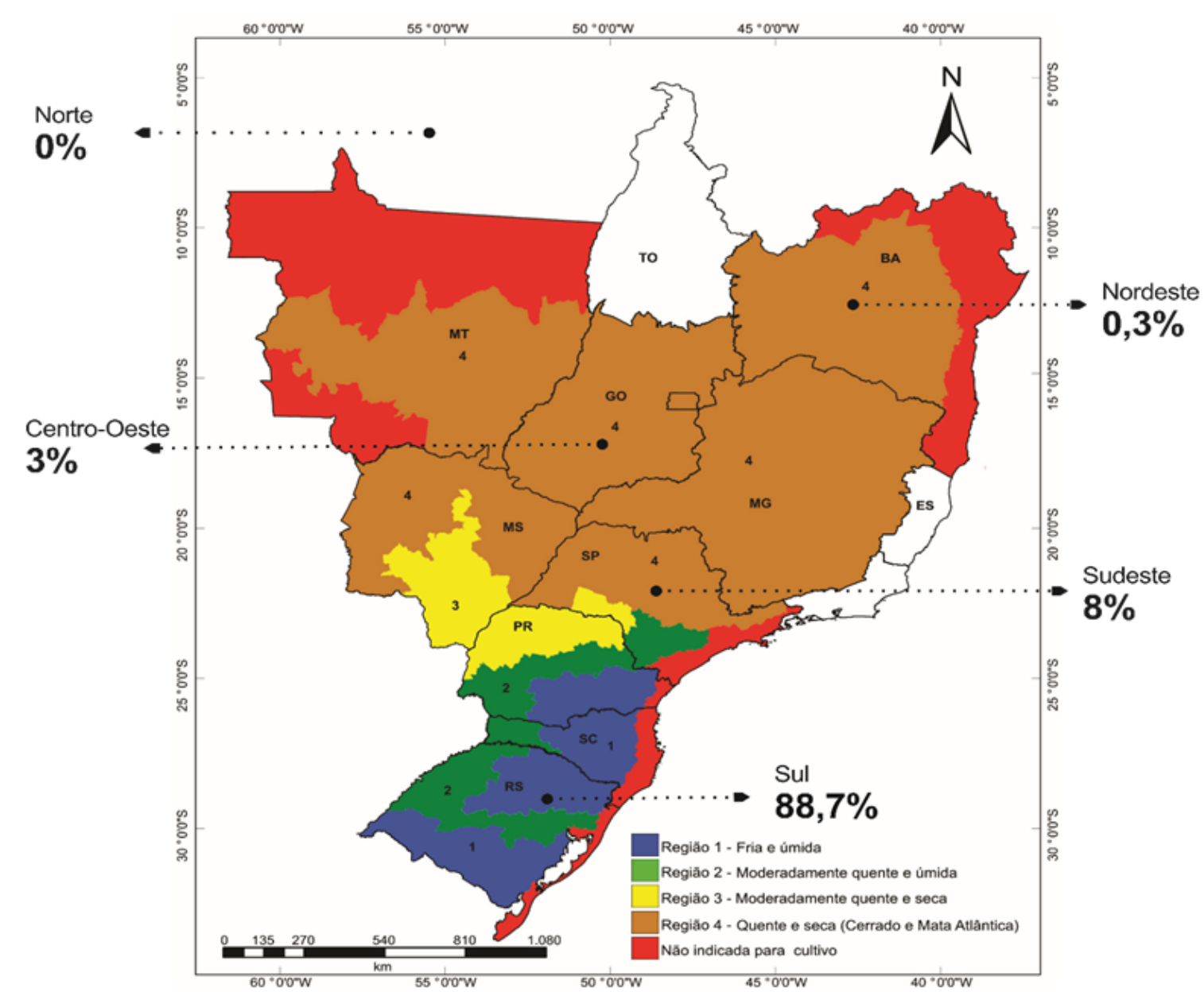

Figura 2. Regiões tritícolas e produção de trigo nas regiões brasileiras. Adaptado de Embrapa 2021.

pouco mais altas do que a região 1 , mas ambas têm uma boa distribuição de chuvas ao longo do ciclo da cultura do trigo. Na região 2, o trigo é semeado mais cedo do que na região 1 . A paisagem agrícola dessas duas regiões é semelhante e, após a safra de verão, composta principalmente por soja (Glycine max (L.) Merr.) e milho, semeia-se primeiro a aveia (Avena spp.) e depois o trigo. No estado do Paraná (o mais setentrional dos três estados da Região Sul), o milho safrinha costuma ser cultivado competindo em área com o trigo no inverno. Porém, quanto mais ao sul, o risco de geadas é maior diminuindo a área de milho safrinha. Assim, a maior área de inverno é ocupada pela de aveia preta (Avena strigosa Schreb.) semeada no outono e, ao redor de $20 \%$ da área cultivável é cultivada com trigo (variando nas microrregiões). Nas direções norte-sul e leste-oeste, há um gradiente das datas de semeadura do trigo. Assim, na Região Sul há uma continuidade e proximidade das lavouras formando pontes verdes que contribuem para epidemias de doenças e pragas. A região 3, quente e moderadamente seca, é uma área de transição entre o clima subtropical do sul do país e tropical da maior parte do Brasil Central. Nessa região, a semeadura do trigo é realizada no final do verão e outono (março-abril). O milho safrinha e o trigo concorrem por área durante o inverno. Como o clima é mais quente, o risco de geadas não é muito alto. No Brasil central (região 4), no Cerrado (equivalente brasileiro às savanas africanas), o trigo é cultivado sob um inverno quente e seco. O clima apresenta uma menor variação de temperatura anual em comparação com o sul do país. No entanto, caracteriza-se por estações chuvosas bem definidas. No outono e inverno (abril a setembro), as chuvas são escassas. O cultivo nessa região, dependendo da época de semeadura, requer irrigação. Assim, existem dois sistemas de cultivo: cultivo de sequeiro quando o trigo é semeado em fevereiro-março; ou cultivo irrigado realizado a partir de abril.

Assim como para a maioria das espécies cultivadas, na cultura do trigo, a ocorrência de doenças fúngicas, bacterianas e virais estão entre os fatores agronômicos que reduzem o rendimento e elevam o custo e o risco de produção (REIS \& CASA 2005; LAU et al. 2011; LAU et al. 2020; SAVARY et al. 2017, 2019). Estima-se que cerca de $20 \%$ da produção global de trigo seja perdida devido à ocorrência de 
doenças (FIGUEROA et al. 2018). Dentre elas, as doenças causadas por vírus representam um grande desafio para a sustentabilidade da agricultura no futuro (BURROWS et al. 2016; JONES \& NAIDU 2019). Aproximadamente 50 bilhões de euros são perdidos anualmente em todo o mundo por conta dos vírus de plantas (PALLÁs et al. 2018). Os vírus são patógenos importantes em espécies do gênero Triticum que são hospedeiras naturais de mais de 40 vírus (Tabela 1), dos quais, alguns apresentam importância econômica (SERFLING et al. 2017). Nas seções seguintes, os vírus que ocorrem em trigo no Brasil serão descritos, especialmente aqueles que apresentam impacto econômico significativo. Tendo como pano de fundo as transformações no sistema de produção e a evolução dos métodos disponíveis para estudo de vírus, serão destacados aspectos históricos dos avanços em etiologia, epidemiologia e manejo dessas viroses (Figura 3). Por fim, serão sumarizados os métodos de diagnóstico disponíveis.

Tabela 1. Vírus que infectam trigo no mundo

\begin{tabular}{|c|c|c|c|c|}
\hline Vírus & Acrônimo & Família & Gênero & Vetor \\
\hline Barley yellow dwarf virus - PAV & BYDV-PAV & Tombusviridae & Luteovirus & Afídeo \\
\hline Barley yellow dwarf virus - MAV & BYDV-MAV & Tombusviridae & Luteovirus & Afídeo \\
\hline Barley yellow dwarf virus - PAS & BYDV-PAS & Tombusviridae & Luteovirus & Afídeo \\
\hline Cereal yellow dwarf virus - RPS & CYDV-RPS & Solemoviridae & Polerovirus & Afídeo \\
\hline Cereal yellow dwarf virus - RPV & CYDV-RPV & Solemoviridae & Polerovirus & Afídeo \\
\hline Maize yellow dwarf virus - RMV & MYDV-RMV & Solemoviridae & Polerovirus & Afídeo \\
\hline Barley yellow dwarf virus - GPV & BYDV-GPV & Solemoviridae & não definido & Afídeo \\
\hline Barley yellow dwarf virus - SGV & BYDV-SGV & Solemoviridae & não definido & Afídeo \\
\hline Wheat yellow leaf virus ${ }^{1}$ & WYLV & Closteroviridae & Closterovirus & Afídeo \\
\hline Mal de rio cuarto virus & MRCV & Reoviridae $^{2}$ & Fijivirus & Cigarrinha \\
\hline Rice black streaked dwarf virus & RBSDV & Reoviridae $^{2}$ & Fijivirus & Cigarrinha \\
\hline Oat sterile dwarf virus & OSDV & Reoviridae $^{2}$ & Fijivirus & Cigarrinha \\
\hline Iranian wheat stripe tenuivirus & IWSV & Phenuiviridae & Tenuivirus & Cigarrinha \\
\hline Rice stripe tenuivirus & RSV & Phenuiviridae & Tenuivirus & Cigarrinha \\
\hline Wheat white spike virus ${ }^{3}$ & WWSV & Phenuiviridae & Tenuivirus & Cigarrinha \\
\hline $\begin{array}{l}\text { Barley yellow striate mosaic cytor- } \\
\text { habdovirus }\end{array}$ & BYSMV & Rhabdoviridae & Cytorhabdovirus & Cigarrinha \\
\hline $\begin{array}{l}\text { Northern cereal mosaic cytorhabdo- } \\
\text { virus }\end{array}$ & NCMV & Rhabdoviridae & Cytorhabdovirus & Cigarrinha \\
\hline Maize yellow striate cytorhabdovirus & MYSV & Rhabdoviridae & Cytorhabdovirus & Cigarrinha \\
\hline $\begin{array}{l}\text { Wheat american striate mosaic cyto- } \\
\text { rhabdovirus }{ }^{1}\end{array}$ & WASMV & Rhabdoviridae & Cytorhabdovirus & Cigarrinha \\
\hline Cereal chlorotic mottle virus ${ }^{1}$ & CCMoV & Rhabdoviridae & não definido & Cigarrinha \\
\hline $\begin{array}{l}\text { Wheat yellow striate alphanu- } \\
\text { cleorhabdovirus }\end{array}$ & WYSV & Rhabdoviridae & Alphanucleorhabdovirus & Cigarrinha \\
\hline $\begin{array}{l}\text { Maize Iranian mosaic alphanu- } \\
\text { cleorhabdovirus }\end{array}$ & MIMV & Rhabdoviridae & Alphanucleorhabdovirus & Cigarrinha \\
\hline Wheat dwarf virus & WDV & Geminiviridae & Mastrevirus & Cigarrinha \\
\hline Wheat dwarf india virus & WDIV & Geminiviridae & Mastrevirus & Cigarrinha \\
\hline Chloris striate mosaic virus & CSMV & Geminiviridae & Mastrevirus & Cigarrinha \\
\hline
\end{tabular}

${ }^{1}$ nenhuma entrada de sequência registrada no GenBank. ${ }^{2}$ Reoviridae, subfamily: Spinareovirinae. ${ }^{3}$ espécie proposta ao ICTV 
Tabela 1. Continuação

\begin{tabular}{|c|c|c|c|c|}
\hline Vírus & Acrônimo & Família & Gênero & Vetor \\
\hline Maize streak virus & MSV & Geminiviridae & Mastrevirus & Cigarrinha \\
\hline Brome mosaic virus & BMV & Bromoviridae & Bromovirus & Besouro \\
\hline Cocksfoot mottle virus & CfMV & Solemoviridae & Sobemovirus & Besouro \\
\hline Barley stripe mosaic virus & BSMV & Virgaviridae & Hordeivirus & Sementes \\
\hline Indian peanut clump virus & IPCV & Virgaviridae & Pecluvirus & Microrganismo em solo \\
\hline Soil-borne wheat mosaic virus & SBWMV & Virgaviridae & Furovirus & Microrganismo em solo \\
\hline Soil-borne cereal mosaic virus & SBCMV & Virgaviridae & Furovirus & Microrganismo em solo \\
\hline $\begin{array}{l}\text { Japanese soil-borne wheat mosaic } \\
\text { virus }\end{array}$ & JSBWMV & Virgaviridae & Furovirus & Microrganismo em solo \\
\hline Chinese wheat mosaic virus & CWMV & Virgaviridae & Furovirus & Microrganismo em solo \\
\hline Wheat stripe mosaic virus ${ }^{3}$ & WhSMV & Benyviridae & não definido & Microrganismo em solo \\
\hline Wheat spindle streak mosaic virus & WSSMV & Potyviridae & Bymovirus & Microrganismo em solo \\
\hline Wheat yellow mosaic virus & WYMV & Potyviridae & Bymovirus & Microrganismo em solo \\
\hline $\begin{array}{l}\text { High plains wheat mosaic emaravi- } \\
\text { rus }\end{array}$ & HPWMoV & Fimoviridae & Emaravirus & Ácaro \\
\hline Triticum mosaic virus & TriMV & Potyviridae & Poacevirus & Ácaro \\
\hline Agropyron mosaic virus & $\mathrm{AgMV}$ & Potyviridae & Rymovirus & Ácaro \\
\hline Wheat streak mosaic virus & WSMV & Potyviridae & Tritimovirus & Ácaro \\
\hline Wheat eqlid mosaic virus & WEqMV & Potyviridae & Tritimovirus & não descrito \\
\hline
\end{tabular}

${ }^{1}$ nenhuma entrada de sequência registrada no GenBank. ${ }^{2}$ Reoviridae, subfamily: Spinareovirinae. ${ }^{3}$ espécie proposta ao ICTV

\section{VIROSES EM TRIGO NO BRASIL}

As viroses e seus agentes causais descritos em trigo no Brasil em ordem cronológica dos seus relatos são:

-1968 - Nanismo-amarelo, barley yellow dwarf virus: Caetano V da R (1968). Nota prévia sobre a ocorrência de uma virose em cereais de inverno no Rio Grande do Sul. [Pelotas: IPEAS, 1968]. 9 p. Revista da Sociedade Brasileira de Fitopatologia p. 53-66.

-1970 - Espiga branca do trigo, brazilian wheat spike virus: Caetano V da R, Kitajima EW, Costa AS (1970). Espiga branca do trigo, uma possível moléstia de vírus. Bragantia, Campinas, v. 29, p. XLI-XLIV. Nota n. 9.

-1976 - Rhabdovirus, espécie não atribuída: Kitajima EW, Cupertino FP, Caetano, V da R (1976). Partículas do tipo rhabdovirus associadas a manchas cloróticas em trigo no Distrito Federal. Fitopatologia (Lima) 11:16-17.

-1978 - Mosaico do trigo, *soil-borne wheat mosaic virus: Caetano $\mathrm{V}$ da R, Kitajima, EW, Costa
AS (1978). Ocorrência e estudos eletrono-microscópicos do vírus do mosaico do trigo, transmitido pelo solo, no estado do Rio Grande do Sul. Fitopatologia Brasileira 3:39-46.

-1986 - Mosaico do Bromus, bromegrass mosaic virus: Caetano $\mathrm{V}$ da $\mathrm{R}$, Formiga ICM, Lin MT, Kitajima EW, Marinho LA (1986). Ocorrência do "Bromegrass Mosaic Virus" em trigo, no estado do Rio Grande do Sul. Fitopatologia Brasileira 11: 358

-2013 - barley yellow dwarf virus -PAV: Mar T B, Lau D, Schons J, Lau EY, Nhani Junior A (2013). Molecular identification based on coat protein sequences of the barley yellow dwarf virus from Brazil. Scientia Agrícola 70:428-434. Primeira confirmação molecular de BYDV-PAV no Brasil até então diagnósticos apenas por sorologia; primeira sequência parcial de RMV. Por sorologia, foram relatados CYDV-RPV e BYDV-MAV (PARIZOTO et al. 2013).

-2013 - Mosaico estriado do trigo, wheat streak mosaic virus: Mar TB, Lau D, Schons J, Pereira PRV da S, Carminatti AJ (2013). Identification and Characterization of Wheat Streak Mosaic Virus Iso- 


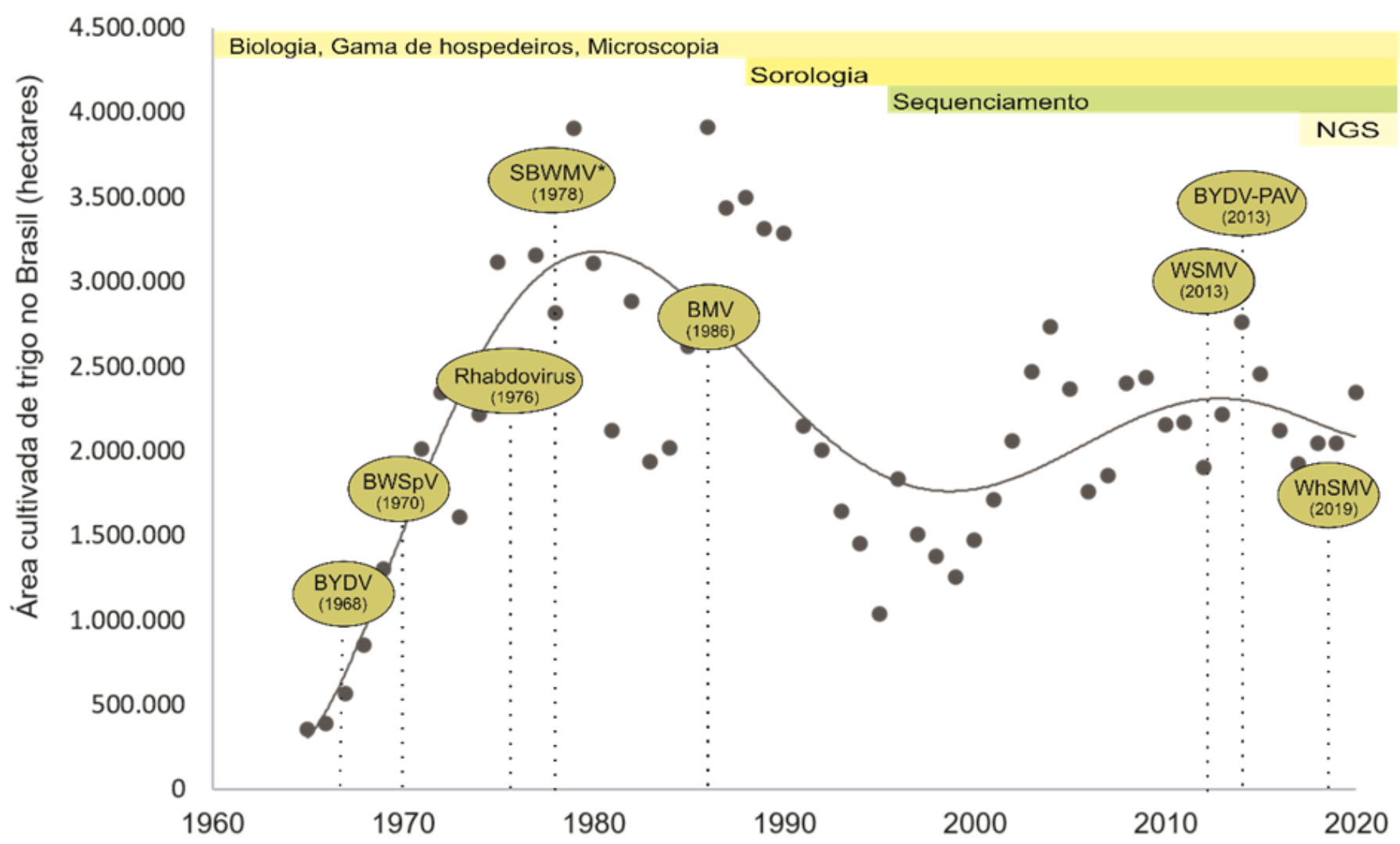

Figura 3. Linha do tempo do progresso da área cultivada com trigo, e o avanço no diagnóstico de vírus relatados no Brasil. $O$ ano apresentado entre parênteses refere-se aquele em que foi publicado trabalho descrevendo detalhadamente a associação entre a patologia e o agente causal diagnosticado com os métodos disponíveis na época. Muitas vezes, esse foi antecedido por relatos de sintomas e hipótese sobre o agente causal em trabalhos preliminares. *A identificação de alguns vírus foi revista com o avanço das técnicas disponíveis conforme apresentado nas seções seguintes. Elaborado pelos autores.

Dados Fonte: 1965-1976 - CTRIN/BANCO DO BRASIL; 1977-2020 - CONAB. https://www.conab.gov.br/info-agro/safras/serie-historica-das-safras

lates in Wheat-Growing Areas in Brazil, International Journal of Agronomy, v. 2013, 6 pages.

-2019 - Mosaico do trigo, wheat stripe mosaic virus: Valente JB, Pereira FS, Stempkowski LA, Farias M, Kuhnem P, Lau D, Fajardo TVM, Nhani Junior A, Casa RT, Bogo A, Silva FN da (2019). A novel putative member of the family Benyviridae is associated with soilborne wheat mosaic disease in Brazil. Plant Pathology 68:588-600.

*Como será detalhado nas próximas sessões, algumas identificações sofreram modificações ao longo do tempo, uma vez que a disponibilidade de novas ferramentas de diagnóstico, principalmente o sequenciamento genético permitiram uma identificação mais precisa dos vírus e seu correto posicionamento taxonômico. Algumas espécies, embora tenham sido relatadas, não foi possível demonstrar a sua ocorrência no país em estudos posteriores, seja por revisão da diagnose, ou talvez por mudanças do sistema agrícola que tornaram sua ocorrência muito rara.

\section{NANISMO AMARELO} busviridae)

barley yellow dwarf virus (Luteovirus, Tomcereal yellow dwarf virus (Polerovirus, Sole-

\section{moviridae)}

A amarelidão dos trigais era relatada desde as primeiras décadas dos anos 1900, mas o marco na história do barley yellow dwarf virus no Brasil ocorreu em 1968 quando sintomas de amarelecimento em trigo foram atribuídos a esse agente etiológico (CAETANO 1968). Ocorre em todas as regiões tritícolas brasileiras, porém sua epidemiologia, danos e manejo são mais conhecidos na Região Sul.

Neste artigo de revisão, serão apresentados os aspectos básicos sobre o BYDV e sua patologia. Porém, devido à importância desse vírus para os cereais de inverno, outro artigo de revisão está sendo preparado para abordar em detalhe a história e os avanços no entendimento das técni- 
cas de diagnóstico, epidemiologia, manejo e controle do BYDV no Brasil (LAU et al. - em preparação).

\section{Etiologia}

Uma das principais doenças dos cereais é a virose conhecida como nanismo amarelo da cevada, no passado e ainda hoje entre os técnicos é referida como "VNAC". Apesar do nome original, os vírus responsáveis por esta doença são capazes de infectar várias espécies de plantas da família Poaceae cultivadas ou não. Cerca de 150 espécies dessa família foram descritas como suscetíveis. Entre os hospedeiros cultivados estão a cevada, o milho, a aveia, o arroz, o centeio e o trigo (D'ARCY 1995).

A doença é causada por um grupo de vírus que são transmitidos por diferentes espécies de afídeos (Hemiptera: Aphididae) de maneira persisten-

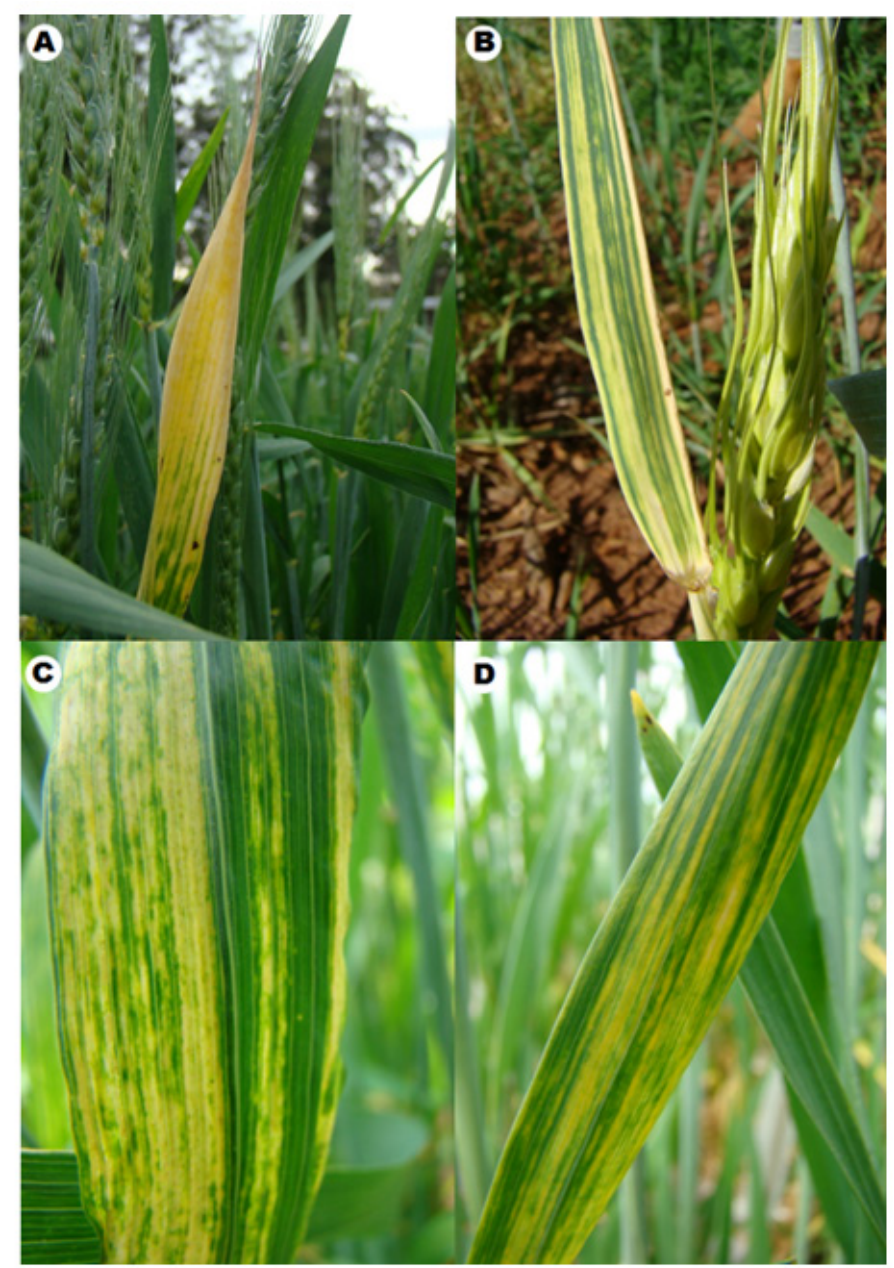

Figura 4. Sintomas de viroses em trigo no Brasil. A) Nanismo amarelo: barley yellow dwarf virus (BYDV, Tombusviridae). B) Espiga branca do trigo: wheat white spike virus (WWSV, Phenuiviridae). C) Mosaico do trigo causado por wheat stripe mosaic virus (WhSMV, Benyviridae). D) Mosaico estriado do trigo causado por wheat streak mosaic virus (WSMV, Potyviridae). Fotos: D. Lau te, circulativa, não-propagativa e sem transmissão transovariana (DOMIER 2012; WANG et al. 2015). A transmissão destes vírus é totalmente dependente de afídeos vetores, não são transmitidos via extrato vegetal tamponado e nem por sementes (WATERHOUSE et al. 1988). Isso ocorre pois em plantas infectadas a localização das partículas virais é restrita às células do floema, exceto em casos de coinfecção como ocorre com o potato leafroll virus (PLRV, Luteovirus) em coinfecção com potato virus Y (PVY, Potyvirus) (ATABEKOV \& DOROKHOV 1984; BARKER 1987).

Existem diversas espécies de afídeos que transmitem os vírus que causam o nanismo amarelo dos cereais, sendo a relação vetor-vírus altamente específica (GRAY \& GILDOW 2003). Consequentemente, a primeira classificação desse grupo de vírus foi realizada com base na especificidade de transmissão pelo afídeo vetor. Rochow (1969) identificou cinco estirpes que eram transmitidas preferencialmente por diferentes afídeos vetores: MAV - Sitobion avenae (Fabricius, 1775), PAV - Rhopalosiphum padi (Linnaeus, 1758) e S. avenae, SGV - Schizaphis graminum (Rondani, 1852), RPV (R. padi) e RMV Rhopalosiphum maidis (Fitch, 1856).

As partículas desses vírus são compostas por capsídeos isométricos de 25 a $38 \mathrm{~nm}$ de diâmetro não envelopados contendo o genoma viral composto por um RNA fita simples de polaridade positiva. O RNA possui tamanho que varia de 5600 a 6000 nucleotídeos (nts) e não apresenta cauda poli-A (MILLER \& RASOCHOVÁ 1997; GRAY \& GILDOW 2003). O advento das técnicas moleculares, o sequenciamento e compreensão da organização do genoma dos vírus permitiu classificar as estirpes propostas por Rochow em diferentes espécies.

As espécies foram originalmente classificadas na família Luteoviridae em dois gêneros: espécies que apresentavam organização genômica similar ao membro tipo Barley yellow dwarf virus-PAV foram classificadas no gênero Luteovirus (recentemente classificado como membro da família Tombusviridae), enquanto que as espécies similares ao membro tipo Potato leaf roll virus foram classificadas no gênero Polerovirus (classificado, recentemente, como membro da família Solemoviridae) (SCHEETS et al., 2020; MILLER \& RASOCHOVÁ 1997).

O sequenciamento completo do genoma, além de ajudar a elucidar a taxonomia, tem permitido identificar novas espécies (ZHANG et al. 2009; KRUEGER et al. 2013). Atualmente, já foram rela- 
tadas oito espécies infectando trigo. No gênero Luteovirus, além de Barley yellow dwarf virus-PAV, são classificadas Barley yellow dwarf virus-MAV, Barley yellow dwarf virus-PAS, Barley yellow dwarf virus- kerll e Barley yellow dwarf virus-PAV-kerlll; no gênero Polerovirus estão classificadas as espécies Cereal yellow dwarf virus-RPS, Cereal yellow dwarf virus-RPV e Maize yellow dwarf virus-RMV. As espécies Barley yellow dwarf virus-GPV e Barley yellow dwarf virus-SGV pertencem à família Solemoviridae, porém ainda não foram classificadas em nenhum gênero (LEFKOWITZ et al. 2018).

Os vírus que causam o nanismo amarelo apresentam poucas diferenças na organização do genoma e na localização das sequências codificadoras (open reading frames - ORFs) (MILLER \& RASOCHOVÁ 1997). Os luteovirus possuem cinco grandes ORFs (ORF 1 - ORF 5). Enquanto os polerovirus, possuem seis grandes ORFs (ORF 0 - ORF 5) (DOMIER 1995; MILLER \& RASOCHOVÁ 1997). A ORF 0, que está presente no genoma dos polerovirus (e ausente nos luteovirus), codifica uma proteína determinante de sintomas e gama de hospedeiros que funciona como uma supressora de silenciamento de RNA. As ORFs 1-5 são comuns aos luteovirus e polerovirus. As ORFs 1 e 2 codificam a proteína RNA-polimerase dependente de RNA ( $R d R p)$ que é traduzida via ribosomal frameshift. A ORF 3 codifica a proteína do capsídeo (CP) e contém a sequência completa da ORF 4. A ORF 4 codifica a proteína do movimento (MP), requerida no movimento célula-célula e infecção sistêmica. Esta região do genoma também contém a ORF3a iniciada por um códon não-AUG, que é traduzida via leaky scanning e codifica uma proteína requerida para o movimento a longa distância. A ORF 5 é expressa via translational readthrough fusionada a ORF 3, levando à tradução do domínio readthrough (-RTD), envolvido na transmissão por afídeos e estabilidade viral. A proteína CP-RTD, além de necessária para a transmissão por afídeos, também facilita o movimento a longa distância dos vírus através do floema das plantas (LIU et al. 2012; SMIRNOVA et al. 2015; LEFKOWITZ et al. 2018).

Além dessas ORFs, a ORF6 foi identificada em alguns luteovirus e polerovirus. A ORF 6 codifica uma pequena proteína ( $\leq 6 \mathrm{kDa}$ ) com função ainda não identificada. A ORF 6 não é conservada e nem requerida para a infectividade viral. No entanto, há evidência de que a $\mathrm{P} 6$ do BYDV-GAV pode atuar como supressora de silenciamento gênico de RNA
(CHALHOUB et al. 1994; DOMIER et al. 2002; MILLER et al. 2002; LIU et al. 2012).

Eventos de recombinação intra e interespécies são frequentemente relatados entre membros dos gêneros Luteovirus e Polerovirus (CHARE \& HOLMES 2006; PAGAN \& HOLMES 2010; BOULILA 2011; $W U$ et al. 2011). Eventos de recombinação entre as proteínas relacionadas à replicação $(R d R p)$ e as proteínas estruturais e de movimento (CP) sugerem que essas duas porções do genoma possuem histórias evolutivas diferentes (CHARE \& HOLMES 2006; PAGAN \& HOLMES 2010). A parte do genoma que codifica para as proteínas estruturais, como a $\mathrm{CP}$, MP e proteínas relacionadas à transmissão por afídeos são conservadas entre membros dos gêneros Luteovirus e Polerovirus, com raras exceções. Em contraste, existem divergências na região do genoma que codifica para as proteínas associadas à replicação. A maquinaria de replicação dos polerovirus e luteovirus são diferentes. As RdRps dos polerovirus são similares às RdRps dos sobemovirus, enquanto os genes envolvidos na replicação e sinais de controle de tradução dos luteovirus são semelhantes aos da família Tombusviridae (MILLER et al. 2002).

\section{Epidemiologia}

Estima-se que a origem das espécies de vírus originalmente classificadas na família Luteoviridae ocorreu há aproximadamente entre 4.000 e 9.000 anos. Portanto, a datação da origem dessas espécies virais se sobrepõe aos eventos de expansão dos sistemas agrícolas, o que sugere que a origem desses vírus pode estar relacionada ao processo de expansão do cultivo de cereais com vistas à produção de alimentos para o consumo humano (FARGETTE et al. 2008; PAGAN \& HOLMES 2010).

O nanismo-amarelo é a doença viral mais amplamente distribuída dentro da família Poaceae. Isso se deve especialmente à ampla gama de hospedeiros dos agentes etiológicos e à eficiente transmissão por várias espécies de afídeos vetores. Um dos principais aspectos epidemiológicos do nanismo-amarelo é a especificidade de transmissão (GRAY \& GILDOW 2003). A especificidade vírus-vetor é apontada como razão para os diferentes comportamentos regionais da doença, cuja prevalência de cada vírus depende da presença, abundância e preferência do vetor que a transmite eficientemente e das espécies de plantas hospedeiras presentes no local (McELHANY et al. 1995; MALMSTROM et al. 2005b). 
No Brasil, assim como em vários outros países, BYDV-PAV é o mais prevalente (PARIZOTO et al. 2013). Nos países responsáveis por $95 \%$ da produção de trigo no mundo, em geral, BYDV-PAV é o vírus mais comum seguido de BYDV-MAV (MORIONES et al. 1993; LISTER \& RANIERI 1995; McELHANY et al. 1995; HALL \& LITTLE 2013; YU et al. 2013; NAJAR et al. 2017). A prevalência de BYDV-PAV está, provavelmente, relacionada com a alta eficiência de transmissão, ampla gama de hospedeiros e ampla distribuição geográfica do seu vetor $R$. padi (MORIONES et al. 1993; McELHANY et al. 1995; HALL \& LITTLE 2013; PARIZOTO et al. 2013; YU et al. 2013).

As espécies de plantas hospedeiras presentes na região também são um fator determinante para a epidemiologia do nanismo amarelo. A composição de plantas hospedeiras (espécies de gramíneas perenes e anuais) podem alterar o movimento do vetor e a dinâmica da doença (McELHANY et al. 1995; MALMSTROM et al. 2005b). Além disso, a presença do vírus em gramíneas exóticas altera a dinâmica das comunidades de plantas hospedeiras locais, pois aumenta indiretamente a incidência da doença nas gramíneas nativas próximas, alterando a dinâmica de competição entre as plantas nativas (MALMSTROM et al. 2005b, a, 2006).

\section{Sintomas}

Os principais sintomas desta virose são: (i) alteração da coloração do limbo foliar que ocorre no sentido do ápice para a base das folhas (Figura 4A), podendo tornar-se amareladas ou avermelhadas; (ii) limbo enrijecido com aspecto lanceolado; (iii) nanismo; (iv) redução da massa foliar; e (v) diminuição do peso e número de grãos (LAU et al. 2011; LAU et al. 2020). Os sintomas nas lavouras ocorrem em grupos de plantas (reboleiras). Linhas de plantas com sintomas também podem ser observadas, que correspondem ao padrão de disseminação por pulgões no interior da lavoura (LAU et al. 2011). Podem também causar a diminuição no crescimento das raízes e redução do afilhamento, retardamento na floração e redução no tamanho da inflorescência, além de provocar esterilidade e falha na formação de grãos, diminuindo o peso e o número de grãos por espiga (CEZARE et al. 2011; LAU et al. 2011; LAU et al. 2020). Assim como para outras viroses, os sintomas causados pelo vírus podem ser difíceis de distinguir dos sintomas causados por deficiências nutricionais e outros estresses abióticos (LAU et al. 2011).

\section{Danos e perdas}

O nanismo-amarelo tem sido descrito como uma doença severa que reduz as características de qualidade em grãos colhidos e afeta a produção de cereais economicamente importantes, como trigo, cevada (Hordeum vulgare L.), aveia (Avena sativa L.) e centeio (Secale cereale L.) (SHAH et al. 2012). As estimativas dos danos causados devido à infecção natural podem variar entre 11 e 33\%, mas em algumas áreas são descritas perdas acima de $86 \%$ (LISTER \& RANIERI 1995). A suscetibilidade e tolerância do hospedeiro ao vírus e ao vetor determina a extensão das perdas. A severidade e a ocorrência da epidemia dependem da interação de vários fatores: cultivar, vírus envolvido, o tempo de infecção, número de vetores e as condições ambientais. O estádio da planta ao ser infectada influencia nos sintomas que se expressam nos vários órgãos, podendo levar à redução do sistema radicular, altura das plantas, massa foliar, número de afilhos, tamanho de espigas, além do número, tamanho, massa e qualidade de grãos (MILLER \& RASOCHOVÁ 1997).

A relação entre incidência da doença e perdas na produção é linear em trigo e aveia: $1 \%$ de incremento da doença causa perda de 20 a $50 \mathrm{~kg}$. ha-1 em trigo e 30 a 60 kg.ha-1 em aveia (MILLER \& RASOCHOVÁ 1997). No Brasil, a doença causa um impacto anual estimado de $20 \%$ na produção de trigo (PEREIRA et al. 2016).

\section{Manejo}

Entre as estratégias de controle desta virose estão as práticas culturais, o controle químico, o controle biológico e a resistência genética da planta hospedeira ao vírus e/ou ao vetor (BILIBIO et al. 2021; CEZARE et al. 2011; LAU et al. 2011; LAU et al. 2020; STOETZER et al. 2014). As práticas culturais incluem o controle de plantas daninhas hospedeiras do vírus, incluindo cereais voluntários, dentro e perto dos campos de produção de trigo. Essas práticas irão minimizar os reservatórios de vírus e vetores nas áreas de cultivo de trigo. O controle biológico utilizando espécies de microhimenópteros teve grande êxito no Brasil, reduzindo significativamente a população de afídeos (SALVADORI \& TONET 2001; SALVADORI \& SALLES 2002; SANTOS et al. 2019).

O controle químico via tratamento de sementes com neonicotinoides pode reduzir as populações de afídeos durante a fase inicial da cultura e as infecções primárias (BILIBIO et al. 2021; SILVA 
et al. 2004; STOETZER et al. 2014). Após o plantio, devem ser realizadas pulverizações de inseticidas em parte aérea quando do atingimento dos níveis de ação ( $10 \%$ de plantas com pulgões). Como os afídeos requerem tempo para adquirir e inocular o vírus, o inseticida é uma estratégia de manejo para diminuir a taxa de infecção.

Quanto ao manejo via genótipo hospedeiro, há variação nos níveis de tolerância das cultivares de trigo brasileiras ao BYDV. As cultivares BR 34 e BR 35 são consideradas fontes de resistência capazes de produzirem descendentes tolerantes à virose (BARBIERI et al. 2001). Em testes de cultivares, a redução na produção de grãos foi em média 30 a 40\%, sendo que em cultivares altamente intolerantes a redução pode chegar a mais de $80 \%$, e em cultivares tolerantes abaixo de $20 \%$ (LAU et al. 2021a).

\section{ESPIGA BRANCA DO TRIGO}

\section{Wheat white spike virus (Tenuivirus, Phenui-} viridae)

O primeiro relato de sintomas da virose da espiga branca do trigo no Brasil ocorreu na região de Pelotas no Rio Grande do Sul em 1948 (DESLAN$D E S$ 1949). A identificação do agente etiológico e ocorrência no Brasil foi realizada a partir de 1970 (CAETANO et al. 1970; CAETANO 1982a). Ocorre nas variadas regiões triticolas, porém com baixa incidência raramente exigindo controle específico.

\section{Etiologia}

Sintomas da espiga branca foram relatados no Brasil inicialmente em 1948, na região de Pelotas, Rio Grande do Sul, onde essa doença estava causando prejuízos nas lavouras de trigo (DESLANDES 1949). A identificação do agente etiológico e ocorrência em outros estados brasileiros foram reportados nos anos 1970. Os pesquisadores o denominaram de vírus da espiga branca do trigo: brazilian white spike virus (BWSpV), com relatos subsequentes em áreas tritícolas do Rio Grande do Sul, Santa Catarina, Paraná, São Paulo, Minas Gerais, Mato Grosso do Sul e Distrito Federal (CAETANO et al. 1970; CAETANO 1982b). Em trabalhos realizados na década de 1970, associaram-se os sintomas dessa doença a partículas virais compatíveis com o gênero Tenuivirus (CAETANO et al. 1970), mas até recentemente a ausência de informações genéticas deixavam pendente a nomeação definitiva pelo Comitê Internacional de
Taxonomia de Vírus (International Committee on Taxonomy of Viruses - ICTV) (ICTV 2021).

Atualmente, os sintomas característicos dessa virose têm sido observados esporadicamente em lavouras de trigo da região Centro-Oeste, Sudeste e Sul do Brasil, principalmente no Estado do Paraná. A partir de amostras de trigo com sintomas típicos dessa virose recentemente coletadas no Paraná, o genoma do vírus associado aos sintomas de espiga branca foi sequenciado. Os resultados são compatíveis para a classificação dentro do gênero Tenuivirus e um novo nome proposto para a espécie foi Wheat white spike virus (PEREIRA et al. 2021).

Os vírus do gênero Tenuivirus, família Phenuiviridae, possuem genoma segmentado constituído por quatro ou mais moléculas de ácido ribonucleico (RNA) de fita simples, de polaridade negativa. A morfologia da partícula viral é filamentosa (alongada flexuosa), apresentando-se na forma espiral, ramificada ou circular. Os critérios taxonômicos para demarcação de espécies no gênero Tenuivirus são: (i) especificidade do vetor; (ii) gama de hospedeiros; (iii) tamanho e número de componentes do genoma; e (iv) identidade de sequência de aminoácidos com limite de $85 \%$ entre quaisquer produtos gênicos correspondentes (pelo menos um) e limite de $60 \%$ de identidade de nucleotídeos entre as regiões intergênicas não codificadoras (ICTV 2021).

O gênero Tenuivirus apresenta nove espécies: Echinochloa hoja blanca tenuivirus, Iranian wheat stripe tenuivirus, Maize stripe tenuivirus, MeIon tenuivirus, Rice grassy stunt tenuivirus, Rice hoja blanca tenuivirus, Urochloa hoja blanca tenuivirus, Rice stripe tenuivirus e European wheat striate mosaic tenuivirus (ICTV 2021). Os vírus pertencentes a essas espécies causam doenças que impactam vegetais economicamente importantes, principalmente monocotiledôneas, como arroz, trigo e milho (FALK \& TSAI 1998), além de um tenuivirus que infecta meloeiro (LECOQ et al. 2018).

A transmissão ocorre por cigarrinhas de maneira persistente propagativa (FALK \& TSAI 1998). As principais cigarrinhas vetoras de tenuivirus são: Laodelphax striatellus - rice stripe virus (RSV), Peregrinus maidis - maize stripe virus (MSpV), Tagosodes orizicolus - rice hoja blanca virus (RHBV), T. cubanus - echinochloa hoja blanca virus (EHBV), Nilaparvata lugens - rice grassy stunt virus (RGSV), Caenodelphax teapae - urochloa hoja blanca virus (UHBV), Ukanodes tanasijevici - Iranian wheat stripe virus - (IWSV), 
Javesella pellucida - european wheat striate mosaic virus (EWSMV) (ICTV 2021). Em estudo realizado no Brasil por Costa et al. (1973) com o vírus da espiga branca em plantas de trigo, a espécie Sogatella kolophon (Kirkaldy 1907) apresentou capacidade de transmissão.

O gênero Tenuivirus apresenta genomas com quatro ou mais segmentos e variam em tamanho de cerca de $9,0 \mathrm{~kb}$ a 1,3 kb e, juntos, constituem um genoma total de cerca de 18-19 kb (FALK \& TSAI 1998). O RNA1 é o maior segmento e apresenta apenas uma região codificadora; os RNA2, RNA3 e RNA4, apresentam duas regiões codificadoras e são ambisensos, exceto para o melon chlorotic spot virus (MeCSV) em que o RNA4 e o RNA5 apresentam apenas uma região codificadora (ICTV 2021).

O RNA1 apresenta o domínio de RNA polimerase dependente de RNA ( $R d R p$ ). A atividade da RNA polimerase de RHBV é capaz de replicar e transcrever os segmentos de RNA in vitro. O RNA2 codifica para as proteínas virais pv2 e pc2 no sentido viral e complementar, respectivamente, essas proteínas apresentam homologia com precursores de glicoproteína, que interagem com o retículo endoplasmático. O RNA3 codifica duas proteínas, NS3 que atua como supressora do silenciamento em RHBV e RSV (XIONG et al. 2009; SÕMERA et al. 2020), e NSvc3 relacionada às interações vírus-vetor em RSV. O RNA4 codifica a proteína NS4 no sentido viral e a proteína pC4 no sentido complementar. Em RSV, as proteínas pC4 e NS4 estão associadas ao movimento do vírus na planta (XIONG et al. 2009; ICTV 2021). A proteína codificada pelo RNA5, no sentido complementar, tem função de estabilidade, replicação e movimento célula a célula (DE MIRANDA et al. 1996).

\section{Epidemiologia}

A epidemiologia desses vírus está diretamente vinculada à dinâmica populacional das cigarrinhas vetoras. Em geral, períodos de estiagem são favoráveis ao aumento populacional desses insetos, mas há poucas informações disponíveis. Há muitas lacunas no conhecimento desse patossistema, tais como a gama de hospedeiros das cigarrinhas e do vírus e as flutuações populacionais anuais, que ainda precisam ser estabelecidas.

\section{Sintomas}

Os sintomas são variáveis e dependem do estádio de desenvolvimento das plantas a época de infecção e temperatura ambiente. Foram relatados amarelecimento pálido em faixas nas folhas de trigo, estrias cloróticas e mosaico estriado (Figura 4B), podendo causar morte da planta antes do perfilhamento. As espigas das plantas afetadas ficam parcialmente e/ou inteiramente de coloração amarelo-pálido, apresentando em alguns casos malformação nas aristas. Ao examinar tecidos de folhas sintomáticas, com auxílio de microscopia de luz e microscopia eletrônica de transmissão, são observadas inclusões intracelulares de aspecto fibroso e enovelado, que se localizam no citoplasma e são formadas por uma massa de partículas filamentosas. Ocorrem alterações ultraestruturais como hipertrofia do nucléolo, degeneração dos cloroplastos e vesicularização do retículo endoplasmático. A degeneração dos cloroplastos pode explicar o branqueamento intenso das folhas. $O$ intenso metabolismo pode estar envolvido na síntese de enormes massas intracelulares, ocorrendo o esgotamento rápido das células e a morte prematura das plantas (KITAJIMA et al. 1971).

\section{Danos e perdas}

Os danos causados pelo vírus da espiga branca são esporádicos. Embora as plantas afetadas tenham redução expressiva do rendimento e até mesmo morte, sua incidência nas lavouras é baixa. Costuma ser mais frequente em parcelas experimentais e em semeaduras de baixa densidade populacional.

\section{Manejo}

Em parcelas experimentais, recomenda-se a aplicação de inseticidas nas próprias parcelas como também nas bordaduras para evitar a transmissão do vírus.

\section{MOSAICO-COMUM DO TRIGO}

\section{Wheat stripe mosaic virus (Benyviridae)}

A história da etiologia do mosaico do trigo no Brasil é complexa. Os primeiros relatos da doença são do final da década de 1960, sendo etiologia viral reportada em 1978 (CAETANO et al. 1978). Ao longo dos anos, distintas espécies de vírus foram associadas à doença culminando na identificação de uma nova espécie em 2019 (VALENTE et al. 2019). 
Ocorre com frequência nas regiões tritícolas 1 e 2, causando danos e requerendo medidas de manejo.

\section{Etiologia}

A doença conhecida como mosaico-comum do trigo foi relatada em trigais no sul do Brasil no final da década de 1960. Estudos preliminares, entre os anos 1960 e 1970, indicaram que a doença estava amplamente disseminada nos campos tritícolas do Rio Grande do Sul (CAETANO et al. 1971; PRESTES et al. 1972). Supunha-se que a doença era causada por um vírus ainda desconhecido no país. Estudos subsequentes revelaram que plantas com mosaico apresentavam o sistema radicular colonizado por um microrganismo, Polymyxa graminis Led. (CAETANO et al. 1971; PIEROBOM et al. 1972), atualmente, classificado como plasmodioforomiceto (NEUHAUSER et al. 2010). Neste período, P. graminis ficou conhecido mundialmente como vetor do soil-borne wheat mosaic virus (SBWMV) relatado na época causando mosaico em trigais nos Estados Unidos, Itália e Japão (McKINNEY 1925; BRAKKE 1971a).

Baseado nestas informações, hipotetizou-se que o mesmo vírus causava mosaico em trigo no Brasil. Em 1978, Vanderlei da Rosa Caetano, um dos principais estudiosos de viroses em cereais do Brasil, juntamente com outros pesquisadores, confirmaram a etiologia viral dos sintomas de mosaico em trigo. As propriedades biológicas do vírus, sintomas, gama de hospedeiros e a morfologia da partícula viral coincidiam com as informações disponíveis na literatura para o SBWMV, conduzindo Caetano e colaboradores a concluírem que o vírus que causava mosaico em trigo nos EUA, Europa e na Ásia, também estava presente no Brasil, sendo que em 1978, o SBWMV foi atribuído como agente etiológico do mosaico-comum do trigo (CAETANO et al. 1978).

Alguns anos depois, o wheat spindle streak mosaic virus (WSSMV, Bymovirus) foi associado a plantas com mosaico comum (CAETANO 1998; SCHONS et al. 2011). Assim como SBWMV, o WSSMV também é transmitido por $P$. graminis (WYLIE et al. 2017). Apesar dessa constatação, estudos subsequentes utilizando testes sorológicos e PCR com oligonucleotídeos iniciadores publicados na literatura internacional, produziram resultados inconclusivos e contraditórios quanto à confirmação dos agentes etiológicos associados à doença no Brasil (CARMINATTI et al. 2011).

Casos em que múltiplos agentes etiológicos podem estar envolvidos em uma patologia e, quando não há conhecimento prévio do agente causal, a ferramenta de sequenciamento de nova geração (do inglês Next Generation Sequencing - NGS) tem sido utilizada para a caracterização de novas espécies virais (ROOSSINCK et al. 2015). Com a utilização desta tecnologia, pesquisadores brasileiros identificaram um novo vírus em plantas com sintomas de mosaico-comum, tentativamente nomeado como wheat stripe mosaic virus (WhSMV), que foi considerado como o verdadeiro agente etiológico do mosaico-comum do trigo (VALENTE et al. 2019). Esse vírus se enquadra na família Benyviridae, composta por espécies virais com genoma segmentado de RNA senso positivo (GILMER \& RATTI 2017). Os principais membros desta família são transmitidos por $P$. graminis ou $P$. betae, sugerindo que o primeiro também esteja associado à transmissão do novo vírus caracterizado no Brasil (VALENTE et al. 2019).

Assim, explicam-se as dificuldades de diagnóstico sorológico e molecular desse vírus. Embora não possa ser refutada a hipótese de que outros agentes causais também causem mosaico em trigo no Brasil, em amostras com sintomas de mosaico submetidas a NGS, esse foi o único vírus encontrado. Além disso, quando amostras de plantas com sintomas de mosaico são submetidas a PCR para detecção de WhSMV, os resultados são positivos. Quando Caetano et al. (1978) concluíram que SBWMV era o agente causal do mosaico-comum no Brasil, indagaram sobre como o vírus havia chegado ao Brasil já que não era transmitido via semente. Por outro lado, a descoberta do novo vírus, novamente levanta questões sobre suas possíveis origens, já que a doença ocorre no Brasil há mais de 50 anos e, recentemente, o WhSMV foi relatado em outros dois países do hemisfério sul: no Paraguai (ESQUIVEL-FARIÑA et al. 2019) e África do Sul (TEREFE et al. 2020). Outros vírus da família Benyviridae como o rice stripe necrosis virus (RSNV) e beet necrotic yellow vein virus (BNYVV) foram relatados anteriormente no Brasil (MACIEL et al. 2006; REZENDE et al. 2015).

A família Benyviridae possui um único gênero, Benyvirus, no qual, com exceção do WhSMV, que ainda não foi classificado em gênero, todas as espécies da família se enquadram (GILMER \& RATTI 2017). Os membros desta família caracterizam-se por apresentar genoma bipartido (RNA 1 e RNA 2) ou multissegmentado (RNAs 1, 2, 3, 4 e até 5), com 
segmentos de RNA de fita simples e senso positivo, separadamente encapsidados em partículas alongadas com simetria helicoidal em forma de bastonete (GILMER \& RATTI 2017).

O WhSMV possui genoma bipartido. O RNA1, com aproximadamente $6.6 \mathrm{~kb}$, tem uma única $\mathrm{ORF}$, que codifica uma poliproteína de 231,7 kDa com funções associadas à replicação viral. Quatro domínios conservados: metiltransferase, helicase, papain-like protease e RNA polimerase dependente de RNA são encontrados nesta poliproteína (VALENTE et al. 2019). O RNA 2 possui aproximadamente 4.9 $\mathrm{kb}$ e, assim como outros membros da família Benyviridae, apresenta seis ORFs (GILMER \& RATTI 2017; LAUFER et al. 2018; VALENTE et al. 2019). A primeira ORF codifica a proteína capsidial (21-23 kDa) e possui um códon de parada que pode ser traduzido pelo ribossomo e produzir uma segunda proteína (readthrough protein - RT) associada com a transmissão pelo vetor (TAMADA \& KUSUME 1991). Na sequência, três ORFs sobrepostas formam o grupamento chamado de "bloco triplo de genes" (TGB1-3) e codificam proteínas de 42, 13 e 15 kDa associadas ao movimento célula-a-célula. Próximo à região 3' do RNA 2, a sexta ORF codifica uma proteína rica em cisteína, com atividade de supressão do silenciamento gênico (CHIBA et al. 2008, 2013; GILMER \& RATTI 2017).

\section{Epidemiologia}

O mosaico-comum do trigo ocorre principalmente nos estados do Rio Grande do Sul, Santa Catarina e na região sul do Paraná (CAETANO 1982b; LAU et al. 2011; LAU 2016). O vírus é transmitido naturalmente às plantas quando ocorre a colonização do sistema radicular do sistema radicular pelo vetor $P$. graminis. $O$ trigo é a principal espécie hospedeira do vírus, mas outras espécies de gramíneas como a cevada, o centeio e o triticale também são relatadas como hospedeiras no Brasil (CAETANO 1982b; DALBOSCO et al. 2002a; STEMPKOWSKI et al. 2020). Experimentalmente, algumas espécies da família Chenopodiaceae podem ser infectadas (CAETANO 1982b).

Estudos aprofundados sobre a epidemiologia do mosaico-comum do trigo são incipientes no Brasil, embora, trabalhos realizados por pesquisadores estrangeiros, com furovírus transmitidos por $P$. graminis, remetem a informações que aparentemente são válidas para o mosaico-comum
(CAETANO 1982b). De acordo com estes estudos, os fatores que exercem maior influência sobre a transmissão natural do vírus pelo vetor estão voltados às condições de temperatura do solo, entre 15 e $18{ }^{\circ} \mathrm{C}$, e umidade do solo próxima ou acima da capacidade de campo (HIMMEL et al. 1992; CHEN \& WILSON 1995; CADLE-DAVIDSON \& BERGSTROM 2004).

O vetor, o plasmodioforomiceto $P$. graminis, foi descrito no Canadá, em 1939, infectando o trigo, a cevada e o arroz (LEDINGHAM 1939). Os plasmodioforomicetos pertencem à classe Phytomyxea, um grupo monofilético de Eucariotos composto por parasitas de plantas biotróficos obrigatórios (NEUHAUSER et al. 2010). Embora não seja considerado um patógeno de plantas, $P$. graminis é eficiente na transmissão de vírus que pertencem a pelo menos quatro gêneros (Furovirus, Pecluvirus, Benyvirus e Bymovirus), causam danos severos, e afetam o rendimento, especialmente, de cereais como cevada, arroz e trigo (KANYUKA et al. 2003; KÜHNE 2009; TAMADA \& KONDO 2013).

$P$. graminis é habitante natural do solo e parasita intracelular de raízes de ampla gama de espécies de gramíneas cultivadas em todo o mundo, incluindo cevada, arroz, centeio, sorgo (Sorghum bicolor (L.) Moench), milheto (Pennisetum glaucum (L.) R. Br.), milho, triticale (Triticum secale Wittmack) e o trigo (ADAMS \& JACQUIER 1994; DELFOSSE et al. 2000; DALBOSCO et al. 2002a). Outras espécies de gramíneas sem importância econômica como Agropyron repens L. Beauv., Bromus inermis Leyss., Bromus tectorum L. e Hordeum jubatum L. são relatadas como hospedeiras de $P$. graminis (BARR 1979).

O ciclo biológico deste microrganismo é complexo e composto por duas fases: esporangial e esporogênica. Na fase esporangial (ciclo primário), ocorre a formação de zoósporos secundários e, na fase esporogênica (ciclo secundário), são produzidos zoósporos primários via a formação de esporos de resistência (NEUHAUSER et al. 2010). O processo de penetração do zoósporo no citoplasma das células das raízes ocorre pelo encistamento, seguido do desenvolvimento de uma estrutura tubular que auxilia na transferência do conteúdo do zoósporo para o interior da célula (TAMADA \& KONDO 2013).

Anteriormente à infecção, o ciclo biológico de $P$. graminis inicia quando um zoósporo primário 
emerge a partir de um esporo de repouso presente no solo (NEUHAUSER et al. 2010). A ativação do esporo de resistência é induzida na presença de um hospedeiro suscetível e água livre no perfil do solo (capacidade de campo) (CAMPBELL 1996). A temperatura do solo também é considerada um fator importante para o desenvolvimento de $P$. graminis, mas a amplitude térmica ótima requerida é variável de acordo com a origem do isolado.

Análises de sequências da região ITS (Internal Transcribed Spacer) do DNA ribossomal revelaram alta diversidade genética entre isolados de $P$. graminis de diversas partes do mundo (WARD \& ADAMS 1998; LEGREVE et al. 2002; WARD et al. 2004), sendo propostos cinco ribotipos: I (f. sp. temperata), II (f. sp. tepida), III (f. sp. tropicalis), IV (f. sp. subtropicalis), e V (f. sp. colombiana) que estão correlacionados com diferenças no requerimento de temperatura e com a gama de hospedeiros (WARD \& ADAMS 1998; LEGREVE et al. 2002; WARD et al. 2004). A temperatura ótima requerida para os ribotipos I e II está entre 15 e $20^{\circ} \mathrm{C}$, enquanto para os demais ribotipos está entre 27 e $30^{\circ} \mathrm{C}$ (LEGREVE et al. 2002).

A aquisição e transmissão do vírus por $P$. graminis não é precisamente conhecida. É suposto que esse processo ocorra com a transferência do conteúdo do zoósporo para o citoplasma da célula hospedeira no momento da infecção, ou, no estágio plasmodial, em que uma fina membrana está entre o citoplasma do vetor e do hospedeiro (TAMADA \& KONDO 2013). A interação específica entre vírus e $P$. graminis ainda apresenta muitas lacunas. Além disso, vírus classificados em diferentes famílias podem ter diferentes mecanismos de interação com o vetor (DRISKEL et al. 2004).

Os vírus podem estar presentes em todos os estágios do ciclo biológico do vetor e, na ausência de hospedeiros suscetiveis, persistem no solo por mais de dez anos em associação com os esporos de resistência. Estas características peculiares do complexo vírus-vetor vêm causando prejuízos importantes na produção de alimentos ao redor do mundo. Uma vez estabelecido em uma determinada área agrícola, o inóculo permanece e o cultivo de espécies suscetíveis é impraticável, visto que não existe, até o momento, controle químico eficiente para o vetor (KÜHNE 2009; TAMADA \& KONDO 2013). Atualmente, a expansão de áreas de cultivo de trigo apresentando sintomas de mosaico-comum vem sendo ob- servada em importantes regiões produtoras do sul do Brasil. Além disso, em condições desfavoráveis, os esporos de repouso podem se manter viáveis no solo em associação com o vírus por tempo indeterminado (KANYUKA et al. 2003).

\section{Sintomas}

O sintoma característico da virose é a presença de mosaico genótipo-específico nas folhas (Figura 4C). Em cultivares mais suscetíveis, o vírus induz sintomas de nanismo e enrosetamento devido ao excesso de perfilhos, a área foliar é reduzida, assim como o sistema radicular é menos desenvolvido (BARBOSA et al. 2001). Nestas condições, o tamanho das espigas e o número de grãos por espiga é reduzido proporcionalmente de acordo com o grau de severidade da doença. No campo, reboleiras de plantas sintomáticas costumam ser observadas nas áreas mais baixas e úmidas, que propiciam ambiente favorável para o movimento dos zoósporos do vetor (P. graminis), embora, em condições de intensa e frequente precipitação pluvial plantas sintomáticas podem ser observadas em qualquer parte do campo (CADLE-DAVIDSON et al. 2006). A severidade dos sintomas e os danos, que levam à queda de rendimento de grãos do trigo são mais pronunciados quando a temperatura média diária se mantém abaixo de $20^{\circ} \mathrm{C}$. O efeito da temperatura está associado ao movimento do vírus da raiz (local de infecção primária) para a parte aérea da planta, assim, a infecção sistêmica das plantas tem uma correlação positiva com temperaturas mais amenas (MYERS et al. 1993; CADLE-DAVIDSON et al. 2006). Além disso, plântulas infectadas precocemente tendem a apresentar sintomas mais severos (SOUZA et al. 2005).

Embora condições favoráveis à infecção e ao desenvolvimento da doença possam ocorrer somente em estádios mais avançados do ciclo do trigo, a observação de sintomas de mosaico-comum em plantas infectadas tardiamente é pouco evidente. Sobretudo, nestas condições, a reprodução do vetor e a replicação do vírus nos tecidos de plantas assintomáticas pode agregar inóculo ao solo para safras seguintes (CAETANO 1982b).

\section{Danos e Perdas}

Os danos causados pelo mosaico-comum do trigo costumam ser limitados às áreas da lavoura onde a presença do inóculo (vetor virulífero) se concentra, contudo, sob condições favoráveis grandes 
áreas podem ser comprometidas (LAU 2014, 2016, 2020; LAU et al. 2014a, b, 2015, 2017, 2019, 2021b). Em campos infestados, a redução do potencial produtivo das cultivares de trigo brasileiras varia de acordo com a resistência e tolerância de cada cultivar e com as condições ambientais em cada ano de cultivo, sendo que essa redução pode ultrapassar 50\% (CAETANO 1982b; LAU 2014, 2016, 2020; LAU et al. 2014a, b, 2015, 2017, 2019, 2021b). Além disso, os grãos produzidos em plantas infectadas apresentam menor qualidade para a panificação, resultando em menor retorno econômico para o triticultor (DALBOSCO et al. 2002b).

\section{Manejo}

As medidas de manejo citadas para redução dos níveis de doença e, consequentemente, das perdas econômicas incluem: (i) rotação de culturas com espécies não hospedeiras; (ii) atraso na semeadura; (iii) aumento dos níveis de fertilização nitrogenada; e (iv) emprego de cultivares resistentes. A rotação de culturas com espécies não hospedeiras como as aveias branca e preta, ervilhaca (Vicia sativa L.) e nabo forrageiro (Raphanus sativus L.) por períodos de 2 e 3 anos é capaz de reduzir a incidência e severidade da doença, resultando em acréscimo significativo no rendimento de grãos em comparação a monocultura de trigo e rotação por apenas 1 ano (STEMPKOWSKI et al. 2020). Entretanto, a rotação de culturas não elimina a doença e plantas infectadas podem ser encontradas em parcelas sob rotação. Acredita-se que em sistemas de rotação de culturas, espécies não hospedeiras do vírus como as aveias, por exemplo, podem hospedar o vetor (DALBOSCO et al. 2002a), mas produzem zoósporos livres de vírus, resultando em redução do inóculo no campo (STEMPKOWSKI et al. 2020).

Avaliações das condições ambiente no momento da semeadura podem permitir escape das condições favoráveis à transmissão viral. A semeadura em solo encharcado favorece a transmissão do vírus e deve ser evitada. O tratamento químico do solo tendo o vetor como alvo não é recomendado, mas em países da Europa e nos EUA, esterilizantes químicos como brometo de metila e formaldeído e outros fungicidas como captan e benomil eram utilizados com bons resultados em pequenas áreas para redução da incidência de SBWMV e do potato mop-top virus (PMTV), contudo eram economicamente e ecologicamente insustentáveis para o ma- nejo em grandes campos de cultivo (CHEN \& WILSON 1995).

A resistência genética tem sido por muito tempo utilizada para manejo de vírus transmitidos por P. graminis (CHEN \& WILSON 1995). Para o mosaico-comum, entretanto, poucas são as fontes de resistência conhecidas e estudadas no Brasil. A cultivar Embrapa 16, lançada em 1994 pela Embrapa Trigo (GOMES et al. 1994), é a principal fonte de resistência ao mosaico-comum do trigo no Brasil (BARBOSA et al. 2001). A caracterização da resistência desta cultivar sugere a presença de dois genes com efeito dominante que regulam a resistência ao vírus do mosaico-comum do trigo (BARBOSA et al. 2001). Os mecanismos de resistência ao WhSMV ainda precisam ser esclarecidos. No caso do SBWMV, a resistência de cultivares de trigo americanas ocorre nas raízes, restringindo o movimento do vírus do sistema radicular para a parte aérea (MYERS et al. 1993). Nesse caso, a avaliação da resistência por meio da inoculação das folhas via extrato vegetal tamponado não se traduz em resistência de campo, pois a resistência parece ser direcionada contra o movimento raiz-parte aérea e não para o movimento sistêmico na parte aérea.

A caracterização da reação ao mosaico-comum das principais cultivares disponíveis no mercado brasileiro é realizada anualmente pela Embrapa Trigo (LAU 2014, 2016, 2020; LAU et al. 2014a, b, 2015, 2017, 2019, 2021b). Estes estudos indicam que entre as cultivares de trigo disponíveis atualmente, há aquelas cuja produção pode ser seriamente comprometida em áreas com mosaico. Por outro lado, há também cultivares com resistência que podem ser empregadas em áreas com a doença.

\section{MOSAICO ESTRIADO DO TRIGO}

\section{tyviridae)}

Wheat streak mosaic virus (Tritimovirus, Po-

O wheat streak mosaic virus e seu vetor, o ácaro Aceria tosichella, foram reportados na América do Sul no início dos anos 2000. No Brasil, em levantamentos para monitorar esse patossistema, tido como em expansão na região, foram relatados o vetor e o vírus na Região Sul. No entanto, em condições de campo as epidemias não são severas ficando os danos mais restritos a ambientes protegidos. 


\section{Etiologia}

O wheat streak mosaic virus (WSMV) foi descrito em 1929 em áreas de cultivo de trigo no Kansas, Estados Unidos (McKINNEY 1937). O vírus é transmitido pelo ácaro Aceria tosichella Keifer (Acaria: Eriophyidae) de maneira circulativa e não-propagativa (SLYKHUIS 1955; OLFIELD 1970; SLYKHUIS 1976a; OLFIELD \& PROESELER 1996). O WSMV infecta espécies da família Poaceae, causando mosaico sistêmico, nanismo e necrose que afetam drasticamente o rendimento de culturas de importância econômica como trigo, milho, aveia, cevada e outras gramíneas (SLYKHUIS 1955; OLFIELD 1970; BRAKKE 1971b; OLDFIELD \& PROESELER 1996; COUTTS et al. 2008b). O WSMV é considerado um dos vírus de maior importância econômica nas regiões de cultivo de trigo no mundo (NAVIA et al. 2013).

A transmissão do WSMV ocorre principalmente por meio do ácaro vetor. $O$ vírus é adquirido apenas na fase de ninfa e pode ser transmitido por ninfas e adultos, reduzindo a eficiência conforme a idade do adulto. Após alimentar-se de plantas infectadas, o vetor permanece virulífero por, pelo menos, 21 dias (SLYKHUIS 1955; DEL ROSARIO \& SILL 1965). O WSMV também pode ser transmitido via semente em pequenas porcentagens, de 0,1 a 0,2\% em trigo (JONES et al. 2005; DWYER et al. 2007; LANOISELET et al. 2008) e em milho em porcentagens ainda menores (HILL et al. 1974).

O WSMV apresenta genoma monopartido, morfologia das partículas e estratégia de tradução típicas da família Potyviridae (NIBLETT et al. 1991; $\mathrm{CHOl}$ et al. 2000). Inicialmente, foi classificado como pertencente ao gênero Rymovirus (ZAGULA et al. 1992; SALM et al. 1996). Atualmente, o Wheat streak mosaic virus é a espécie tipo do gênero Tritimovirus, Potyviridae (WYLIE et al. 2017). As partículas possuem simetria helicoidal medindo $63 \pm 5 \AA$ de raio (PARKER et al. 2005; McDONALD et al. 2010), 700 $\mathrm{nm}$ de comprimento e $15 \mathrm{~nm}$ de diâmetro (BRAKKE 1971b; BRAKKE et al. 1987). O genoma é composto por 9.384 nucleotídeos de RNA fita simples (positivo), com uma proteína (VPg) ligada ao terminal 5' e uma cauda poli-A no terminal 3'. O RNA é traduzido em uma única poliproteína processada por três proteinases gerando de 8 a 10 proteínas maduras (ALLISON et al. 1986; DOUGHERTY \& CARRINGTON 1988; DOUGHERTY \& SEMLER 1993; STENGER et al. 1998; URCUQUI-INCHIMA et al. 2001; ADAMS et al. 2005; CHUNG et al. 2008).
As principais proteínas derivadas da poliproteína são: P1, HC-Pro (Helper Component-proteinase), P3, Cl (Cylindrical Inclusion protein), Nla-Pro (Nuclear Inclusion protein), NIb (Nuclear Inclusion protein b) e CP (proteína capsidial). A proteína P1 é uma serina endopeptidase com função de protease, promovendo a clivagem entre si e a HC-Pro e é requerida na amplificação do genoma (VERCHOT et al. 1991; VERCHOT \& CARRINGTON 1995; MERITS et al. 1999; CHOI et al. 2002). A HC-Pro do WSMV exerce função de protease (STENGER et al. 2006a), promovendo a clivagem da poliproteína viral por auto-proteólise na sua região terminal (CARRINGTON \& HERNDON 1992). A HC-Pro é essencial na transmissão pelo ácaro (STENGER et al. 2005, 2006a; YOUNG et al. 2007), na replicação, no movimento (STENGER et al. 2005) e também pode afetar a virulência (STENGER \& FRENCH 2004) e a patogenicidade (STENGER et al. 2006b). Entretanto, diferenças na gama de hospedeiros entre os tritimovirus não são determinadas pela HC-Pro (STENGER \& FRENCH 2004). A HC-Pro também está envolvida na supressão do silenciamento pós-transcricional (PTGS) (ANANDALAKSHMI et al. 1998; YOUNG et al. 2007).

Em infecções com WSMV, a proteína P3 está envolvida na replicação do RNA viral e afeta o movimento do genoma ( $\mathrm{CHOI}$ et al. 2005). No cistron P3 da poliproteína ocorre uma pequena ORF, conservada entre os membros da família Potyviridae, que codifica a proteína P3N-PIPO, que auxilia no movimento célula a célula (VIJAYAPALANI et al. 2012). A proteína $\mathrm{Cl}$ promove a hidrólise de ribonucleotídeos necessária para a função de RNA helicase essencial na replicação do genoma viral (FERNÁNDEZ et al. 1995, 1997) e facilita o movimento célula a célula (LANGENBERG 1993; CARRINGTON et al. 1998).

Outra proteína com função de protease é a Nla-Pro, que promove a clivagem entre si e NIb e CP (CARRINGTON \& DOUGHERTY 1987a, b) e é essencial na expressão do genoma (DOUGHERTY \& SEMLER 1993). A Nla está relacionada a VPg no genoma (SHAHABUDDIN et al. 1988; MURPHY et al. 1990). A região mais conservada da poliproteína viral entre os membros da família Potyviridae é a NIb, onde está codificada a RNA polimerase (DOMIER et al. 1986; STENGER et al. 1998). Na região $\mathrm{COOH}$-terminal da poliproteína está codificada a $\mathrm{CP}$, seguida da região UTR (untranslated region) e cauda poli-A (NIBLETT et al. 1991). Nos potyvirus, a CP está relacionada com a especificidade de transmissão pe- 
los afídeos (ATREYA et al. 1991, 1995; GAL-ON et al. 1992) e auxilia no movimento célula a célula e longa distância (DOLJA et al. 1994; ROJAS et al. 1997; LÓPEZ-MOYA \& PIRONE 1998). A região N-terminal da CP do WSMV está envolvida com especificidade de hospedeiro e movimento a longa distância (TATINENI et al. 2011). As divergências entre o genoma do WSMV e membros da família Potyviridae, estão localizadas especialmente na região onde está codificada a CP e porção N-terminal da HC-Pro, ambas associadas à transmissão (NIBLETT et al. 1991; STENGER et al. 1998; CHOl et al. 2000).

\section{Epidemiologia}

A grande importância econômica do WSMV resulta dos efeitos sobre a produção das plantas infectadas e da eficiente transmissão, por meio do ácaro eriofiídeo $A$. tosichella, embora também possa ocorrer por sementes em pequenas porcentagens (SLYKHUIS 1955; HILL et al. 1974; JONES et al. 2005; DWYER et al. 2007; LANOISELET et al. 2008). Após a chegada em um hospedeiro, o ácaro se estabelece nas partes mais protegidas da planta, o que evita a ação de predadores e reduz a desidratação e o desalojamento (chuva e vento) (NAVIA et al. 2013).

O complexo vírus-vetor está amplamente distribuído em regiões agrícolas do mundo e diferentes estirpes do vírus ocorrem nos Estados Unidos, México e Eurásia (BRAKKE 1971b; McNEIL et al. 1996; CHOI et al. 2001; SÁNCHEZ-SÁNCHEZ et al. 2001; STENGER et al. 2002). A primeira detecção do WSMV no hemisfério sul ocorreu na Austrália, sendo os isolados virais similares aos da região Noroeste Pacífico Americana (APNW -"American Pacific Northwest") (ELLIS et al. 2003, 2004; STENGER \& FRENCH 2009).

Na América do Sul, até 2002, o complexo $A$. tosichella e WSMV não havia sido detectado e era considerado praga quarentenária. Em 2002, foram observadas plantas com sintomas de mosaico e análises subsequentes revelaram a presença do WSMV na área central da província de Córdoba, Argentina (TRUOL et al. 2004) e, em 2004 o vetor $A$. tosichella foi detectado associado a plantas infectadas pelo WSMV. Até 2006, o complexo já havia sido detectado nas províncias de Tucumán, Entre Rios, La Pampa, Buenos Aires, Córdoba, Salta, Santa Fé e Santiago del Estero (NAVIA et al. 2006).

Outro vírus transmitido por $A$. tosichella é o high plains wheat mosaic virus (HPWMoV), classificado no gênero Emaravirus (TATINENI et al. 2014).
O HPWMoV foi identificado pela primeira vez na Argentina, em 2006, em plantas coinfectadas por WSMV (TRUOL \& SAGADIN 2007). Infecções mistas entre WSMV e HPWMoV são comumente encontradas em trigo, milho, aveia e cevada, além de gramíneas não cultivadas em diferentes regiões produtoras de trigo na Argentina (ALEMANDRI et al. 2013, 2017).

Os isolados de WSMV descritos na Argentina assim como os isolados Australianos são semelhantes aos encontrados na região APNW. O WSMV pode ter sido introduzido, nesses países, a partir de uma fonte comum e/ou a linhagem introduzida possui maior taxa de transmissão via semente do que as outras (STENGER \& FRENCH 2009). Os isolados de WSMV provenientes da Austrália possuem uma taxa de transmissão via semente entre 0,2 e 0,5\% (SMITH et al. 2005; DWYER et al. 2007; LANOISELET et al. 2008).

Em 2006, A. tosichella foi encontrado no Brasil infestando lavouras de trigo em quatro municípios da região noroeste do estado do Rio Grande do Sul: Passo Fundo, Palmeira das Missões, São Luiz Gonzaga e Santo Antônio das Missões (PEREIRA et al. 2009).

A presença do vetor também foi relatada no Uruguai, em 2007, nas províncias de Colônia e Rio Negro, tendo trigo, azevém (Lolium multiflorum Lam.) e Bromus unioloides (Kunth) como hospedeiros (CASTIGLINI \& NAVIA 2008). Desde a primeira detecção no Brasil até 2011, a ocorrência do ácaro foi confirmada em 18 municípios da região norte e noroeste do Rio Grande do Sul e um do oeste de Santa Catarina, ocorrendo em 11 hospedeiros: trigo, aveia, capim rabo de burro (Andropogon bicornis L.), papuã (Brachiaria plantaginea (Link) Hitchc.), braquiária (Brachiaria decumbens Stapf), capim rhodes (Chloris polydactyla (L.) Sw.), capim amargoso (Digitaria insularis (L.) Fedde.), milhã (Digitaria horizontalis Willd.), azevém, pasto italiano (Pennisetum americanum (L.) Leeke) e capim massambará (Sorghum halepense (L.) Pers.) (NAVIA 2009; PEREIRA et al. 2009; LAU 2012). Em levantamentos conduzidos entre 2009 e 2012, observou-se a ampliação da distribuição do ácaro no Brasil, sendo encontrado em municípios do Rio Grande do Sul, Santa Catariana e Paraná principalmente em meses com temperaturas mais altas, em 23 hospedeiros diferentes, sendo a maioria trigo e azevém. Apesar da ampliação da área de ocorrência, as populações de $A$. tosichella 
no Brasil são pequenas, não sendo observados danos no campo (PEREIRA et al. 2013).

Entre 2009 e 2011, após um grande esforço amostral nas regiões produtoras de trigo do Rio Grande do Sul, Santa Catarina, Paraná e Mato Grosso do Sul, a presença do WSMV foi detectada no Brasil em plantas de trigo com sintomas de mosaico mantidas em casa de vegetação e em amostras de campo coletadas nos municípios de São Luiz Gonzaga e Passo Fundo, Rio Grande do Sul. Comparações das sequências dos genes da CP e VPg-Nla indicam que os isolados de WSMV brasileiros são similares aos isolados argentinos. Entretanto, infecções severas em campo ainda não foram observadas (MAR et al. 2013a, b).

Até o momento, o HPWMoV não foi detectado no Brasil, mas já foram interceptadas sementes de milho infectadas pelo vírus no Laboratório de Quarentena Vegetal do Cenargen (SANCHES \& MARTINS 2013; BOTELHO et al. 2016).

\section{Sintomas}

O WSMV geralmente ocorre em reboleiras conforme a distribuição do vetor, causando mosaico sistêmico, nanismo e necrose que afetam drasticamente o rendimento da cultura do trigo (McKINNEY 1949; SLYKHUIS 1955; BRAKKE 1971b; STYER \& NAULT 1996; COUTTS et al. 2008b). Os primeiros sintomas da infecção são estrias verdes paralelas as nervuras das folhas, essas estrias tornam-se amarelas formando padrões de amarelo e verde em linhas descontínuas, chamado de mosaico (Figura 4D), seguido da indução de sintomas nas folhas jovens em desenvolvimento. Posteriormente, as riscas tornam-se manchas maiores resultando em clorose cobrindo grande parte da folha, seguida por necrose em plantas severamente afetadas (MARTIN 1978; STYER \& NAULT 1996).

Além da transmissão pelo vetor, o WSMV também pode ser inoculado via extrato vegetal tamponado (McKINNEY 1949), com expressão dos sintomas entre 6 e 8 dias após a inoculação, quando as plantas são mantidas entre 20 e $25{ }^{\circ} \mathrm{C}$ (STYER \& NAULT 1996). Em geral, como ocorre com muitos vírus de plantas, quanto mais precoce é a infecção, mais severos são os sintomas (McKINNEY 1949; MARTIN et al. 1984; COUTTS et al. 2008b, a). Em ambos os casos, inoculação pelo vetor ou via extrato vegetal tamponado, a infecção precoce causa nanismo e a planta pode produzir vários perfilhos pequenos (McKINNEY 1949; KAPOORIA \& NDUNGURU 2004). As plantas infectadas precocemente são severamente atrofiadas, mostram estrias pardas e sintomas de mosaico nas folhas, produzem menos sementes e as sementes são menores. Quando as condições favorecem a infecção precoce, o rendimento fica drasticamente comprometido podendo consistir apenas de uma pequena quantidade de grãos murchos, ou formam apenas espigas estéreis sem sementes (STYER \& NAULT 1996; COUTTS et al. 2008b, a).

Os sintomas induzidos pelo vírus são influenciados pelo ambiente como solo, fertilidade, temperatura, pluviosidade, radiação solar assim como o estádio da planta quando infectada e o genótipo (MARTIN et al. 1984; COUTTS et al. 2008b, a). No campo, a direção e intensidade dos ventos são fatores de dispersão do ácaro vetor, podendo também influenciar na distribuição da virose e, consequentemente, dos sintomas (SLYKHUIS 1955; COUTTS et al. 2008b, a).

\section{Danos e perdas}

Os prejuízos causados pelo WSMV em áreas de produção de trigo nos Estados Unidos e Canadá têm sido significativos, com relatos de perdas de até $100 \%$ quando a infecção ocorre no outono (SIM et al. 1988; HUNGER et al. 1992; CHRISTIAN \& WILLIS 1993; McNEIL et al. 1996; MASUMI et al. 2001; FRENCH \& STENGER 2003; DWYER et al. 2007; HADI et al. 2011). Na região das grandes planícies dos Estados Unidos, onde o WSMV é considerado uma das doenças virais mais importantes para o cultivo de trigo, as perdas anuais são de 2 a 5\%, mas ocasionalmente podem ocorrer surtos que causam perdas de até $100 \%$ (SIM et al. 1988; HUNGER et al. 1992; CHRISTIAN \& WILLIS 1993; McNEIL et al. 1996; MASUMI et al. 2001; FRENCH \& STENGER 2003; DWYER et al. 2007; HADI et al. 2011). O cultivo de trigo durante a primavera nesta região pode ter seu rendimento afetado em 31,9 a 98,7\% com redução no peso de mil grãos entre 10,8 e 49,3\% (EDWARDS \& MCMULLEN 1988).

Um dos estados com maior incidência de WSMV é o Kansas, Estados Unidos. Em 1949, o prejuízo causado pelo vírus foi estimado em 30 milhões de dólares (FELLOWS \& SILL 1955). Em 1974, estimaram-se perdas de 816 mil toneladas e em 1981, 571 mil toneladas (MARTIN et al. 1984; SIM et al. 1988). Entre 1987 e 1991, a virose tornou-se a doença mais 
importante para a cultura do trigo no estado, causando uma redução de $13 \%$ no rendimento da safra em 1988 (SIM et al. 1988; CHRISTIAN \& WILLIS 1993).

Os maiores danos ocorrem quando o trigo é infectado precocemente (McKINNEY 1949; MARTIN et al. 1984; COUTTS et al. 2008a, b). Além do estádio da planta no momento da infecção, a interação com o ambiente também afeta a severidade da doença (SHAHWAN \& HILL 1984; HUNGER et al. 1992). Dependendo do cultivar, os danos podem variar de 50 a 91\% (HUNGER et al. 1992), infecção por incidência pode reduzir o rendimento em $40,7 \%$ e o peso de mil grãos em 10,6\% (SEIFERS \& MARTIN 1988) e $100 \%$ pode ocasionar redução aproximada no rendimento de $74 \%$ e afetar em até $41 \%$ o peso de mil grãos (MASUMl et al. 2001).

\section{Manejo}

Plantas voluntárias de trigo e hospedeiros alternativos servem de refúgio aos ácaros vetores no intervalo entre os cultivos e são fontes de manutenção e propagação do WSMV (THOMAS \& HEIN 2003; JIANG et al. 2005; COUTTS et al. 2008b, a). Além disso, o ácaro tem um grande potencial de dispersão pelo vento (SLYKHUIS 1955; COUTTS et al. 2008a, b). A sobrevivência e dispersão do ácaro vetor são os principais fatores que influenciam na propagação do WSMV (THOMAS et al. 2004). Essas condições favorecem a infecção precoce nas lavouras que dificultam o controle (SOMSEN \& SILL 1970; SHAHWAN \& HILL 1984; THOMAS \& HEIN 2003; JIANG et al. 2005).

O controle químico é pouco efetivo contra o ácaro (THOMAS et al. 2004). A principal estratégia de manejo do WSMV envolve a redução do número de ácaros através do controle de plantas de trigo voluntárias e hospedeiros alternativos (SLYKHUIS 1955; SOMSEN \& SILL 1970; SHAHWAN \& HILL 1984; JIANG et al. 2005). As práticas culturais como alterar a época do plantio, destruir as plantas de trigo voluntárias e as gramíneas hospedeiras e o isolamento do plantio são recomendadas (THOMAS et al. 2004).

A resistência genética e o manejo preventivo são as estratégias mais eficientes no controle da virose. Na Argentina, o melhoramento é acompanhando pela seleção assistida pelos marcadores dos genes Wsm-1 e Cmc3 (BAINOTTI et al. 2013). Em ensaios de transmissão via extrato vegetal tamponado, os isolados brasileiros infectaram cultivares brasileiras de aveia e causaram sintomas em trigo, cevada, centeio, triticale e milho (LAU \& PEREIRA 2013; MAR et al. 2013a). Nesses ensaios, houve variação na severidade e frequência de sintomas de cultivares de trigo (Embrapa 16, BRS Guabiju e BRS Timbaúva) e triticale (RS Saturno e BRS Ulisses), indicando que há variação na interação vírus-hospedeiro (MAR et al. 2013a).

As principais cultivares empregadas em áreas de trigo do Rio Grande do Sul, em 2012, eram suscetíveis ao WSMV. Inoculadas em início de ciclo, as plantas infectadas apresentaram redução média de $46 \%$ de estatura, $40 \%$ do número de espigas, $73 \%$ de massa seca da parte aérea, $80 \%$ da massa de raízes, $70 \%$ do número de grãos e $76 \%$ do peso total de grãos em relação às plantas não infectadas (LAU \& PEREIRA 2013). Em avaliações a campo e em casa de vegetação, oito cultivares brasileiras (Fundacep Nova Era, CD 123, Marfim, BRS Guamirim, Fundacep Raizes, CD 121, BRS 208 e CD 114) e a cultivar argentina KS93WGR27/ProINRA Super foram tolerantes ou não foram infectadas pelo isolado de WSMV GM2009, mas foram suscetíveis ao isolado MJ-2010. Apenas a cultivar americana MACE foi resistente a ambos os isolados (ALEMANDRI et al. 2013).

\section{OUTROS VÍRUS RELATADOS NO BRASIL}

Outros vírus foram relatados no Brasil em algum momento da história, mas que não tiveram confirmação posterior por métodos moleculares, ou que não são encontrados em lavouras.

\section{Brome mosaic virus - BMV}

O brome mosaic virus, BMV (Bromovirus, Bromoviridae) já foi relatado ocorrendo na Finlândia, África do Sul, Estados Unidos, Canadá, Rússia, Brasil, na antiga URSS e na antiga lugoslávia (ClMMYT; CAETANO et al. 1990). Sua transmissão no campo não está totalmente elucidada. Porém, em laboratório, pode ocorrer mecanicamente ou por vetores invertebrados, principalmente besouros da família Chrysomelidae (GÁBORJÁNYI \& SZABOLCS 1987), nematoides do gênero Xiphinema (FRITZSCHE 1975) e afídeos (RYBICKI \& WECHMAR 1982).

O BMV apresenta um genoma com três segmentos de RNA de fita simples (positivos) (AHLQUIST et al. 1990). Os três RNAs genômicos são encapsulados em três virions icosaédricos separados, mas o RNA subgenômico 4 é co-encapsulado com o RNA3 (NI et al. 2014). O RNA 1 codifica uma proteína que contém um domínio metiltransferase e um do- 
mínio semelhante à helicase. O RNA 2 codifica uma RNA polimerase dependente de RNA (SULLIVAN \& AHLQUIST 1997). Os produtos gênicos dos RNA 1 e 2 estão envolvidos na replicação viral. O RNA 3 codifica a capa proteica (CP) e a proteína de movimento (PM) (AHLQUIST et al. 1990). Segundo Caetano (1998), o BMV causa um mosaico esbranquiçado e é transmitido por Diabrotica speciosa (Germar, 1824) (Coleoptera: Chrysomelidae). Há estirpes que se diferenciam pela intensidade dos sintomas e foram constatadas ocorrências de até $50 \%$ de plantas de trigo infectadas em lavouras.

\section{Wheat spindle streak mosaic virus - WSSMV}

O WSSMV foi relatado pela primeira vez na América do Norte, em 1960, em Ontário, Canadá (SLYKHUIS 1960). Posteriormente, sua ocorrência foi relatada na França (SIGNORET et al. 1977), Estados Unidos da América (WILLIAMS et al. 1975; WIESE 1977; LOMMEL 1986), Índia (AHALAWAT et al. 1976), Itália (RUBIES-AUTONELL \& VALLEGA 1987), China (JIANPING 1993), Croácia (VRANDEČIĆ et al. 2015). Esse vírus pertence ao gênero Bymovirus, família Potyviridae e é transmitido por $P$. graminis (SLYKHUIS 1976b; 1996; INOUYE 1996).

O WSSMV apresenta partículas filamentosas (alongadas e flexuosas), contendo dois RNAs genômicos que são traduzidos em um polipeptídeo, sendo então auto clivado em proteínas funcionais (ZIEGLER \& KASTIRR 2016). A poliproteína codificada do RNA 1 compreende a parte C-terminal da proteína de inclusão citoplasmática $(\mathrm{Cl})$, inclusão nuclear a e b (Nla e NIb) - proteinases, a RNA polimerase e a CP (WYLIE et al. 2017).

Os relatos de WSSMV no Brasil foram feitos no Brasil por Caetano (1998) e Schons et al. (2011) e estão atrelados a observações de sintomas, associação com vetor, presença de partículas e testes sorológicos. Porém, análises moleculares recentes não têm confirmado a sua ocorrência no Brasil.

\section{Barley stripe mosaic virus - BSMV}

Capaz de infectar trigo e com transmissão eficaz por sementes, o barley stripe mosaic virus (BSMV) foi relatado em cevada introduzida no Brasil. Porém, após confirmação do diagnóstico, o material contaminado foi imediatamente eliminado e a introdução suspensa (ANJOS et al. 1987). Considera-se, portanto, que o vírus não ocorre em condições de lavoura e é considerado praga quarentenária (MARINHO et al. 2004; JORCELINO et al. 2019).

\section{DIAGNOSE DAS PRINCIPAIS VIROSES NO EM TRIGO NO BRASIL}

O desenvolvimento de ferramentas para o diagnóstico dos vírus que infectam trigo tem evoluído ao longo dos anos, influenciando no manejo e controle das viroses (FAJARDO \& NICKEL 2014). Os métodos de diagnóstico disponíveis para uma determinada virose dependem do conhecimento adquirido para aquele agente etiológico. Os métodos de diagnóstico disponíveis para os vírus que infectam trigo já detectados no Brasil estão apresentados na Tabela 2.

\section{CONSIDERAÇÕES FINAIS}

Desde o primeiro relato oficial de um vírus em trigo no Brasil, em 1968, e da expansão da cultura no país, mais de 50 anos se passaram. Esta história, assim como da ciência em geral, tem sido reple-

Tabela 2 - Métodos de diagnóstico disponíveis para os principais vírus que infectam trigo no Brasil

\begin{tabular}{|c|c|c|c|}
\hline Vírus & Biológico & Sorológico & Molecular \\
\hline BYDV & Transmissão apenas por afídeos vetores para cereais de inverno & DAS ELISA ${ }^{1}$ & RT-PCR ${ }^{2}$ \\
\hline BWSpV & Transmissão por cigarrinhas & - & RT-PCR \\
\hline \multirow[t]{2}{*}{ WhSMV } & $\begin{array}{l}\text { Transmissão via extrato vegetal tamponado pouco eficiente } \\
\text { para cereais de inverno. }\end{array}$ & $\begin{array}{l}\text { Em desenvolvi- } \\
\text { mento }\end{array}$ & RT-PCR \\
\hline & Indicadora Chenopodium spp. & & \\
\hline WSMV & $\begin{array}{l}\text { Transmissão via extrato vegetal tamponado muito eficiente } \\
\text { para trigo }\end{array}$ & DAS ELISA & RT-PCR \\
\hline
\end{tabular}

'DAS ELISA - Ensaio de imunoabsorção enzimática por sanduíche de duplo anticorpo - em inglês - Enzyme-Linked Immunosorbent Assay by double antibody sandwich. ${ }^{2} \mathrm{RT}$-PCR - Reação da transcriptase reversa seguida pela reação em cadeia da polimerase - em inglês - Reverse transcription polymerase chain reaction 
ta de descobertas e muitos avanços potencializados pelas novas tecnologias disponíveis para o estudo e entendimento dos vírus. Ao longo desse período, as mais variadas soluções foram encontradas para reduzir os danos e as consequentes perdas à produção causados pelas viroses. A identificação e caracterização dos vírus e de sua variabilidade genética está mais precisa e isso tem reflexo nas estratégias de manejo e controle, que passaram a fazer uso da resistência genética e de práticas que visam a interferir no ciclo do vírus atuando principalmente sobre seu vetor. Em um mundo cada vez mais integrado, as introduções de vírus e seus vetores também se tornaram mais prováveis e seu monitoramento preventivo mais importante.

\section{REFERÊNCIAS}

ADAMS MJ, ANTONIW JF, BEAUDOIN F (2005). Overview and analysis of the polyprotein cleavage sites in the family Potyviridae. Molecular Plant Pathology 6:471-487. (https://doi. org/10.1111/j.1364-3703.2005.00296.x).

ADAMS MJ, JACQUIER C (1994). Infection of cereals and grasses by isolates of Polymyxa graminis (Plasmodiophorales). Annals of Applied Biology 125:53-60. (https://doi.org/https://doi. org/10.1111/j.1744-7348.1994.tb04946.x).

AHALAWAT YS, MAJUMDAR A, CHENULU VV (1976). First record of Wheat spindle streak mosaic in India. Plant Disease Reports 60:782-783.

AHLQUIST P, ALLISON R, DEJONG W, JANDA $M$, KRONER P, PACHA R, TRAYNOR P (1990). Molecular Biology of Bromovirus Replication and Host Specificity. Viral Genes and Plant Pathogenesis 144-155. (https://doi.org/10.1007/978-14612-3424-1_15).

ALEMANDRI V, MATTIO MF, RODRIGUEZ SM, TRUOL G (2017). Geographical distribution and first molecular detection of an Emaravirus, High Plains wheat mosaic virus, in Argentina. European Journal of Plant Pathology 149:743-750. (https://doi.org/10.1007/s10658-017-1207-8).

ALEMANDRI VM, MATTIO MF, DUMÓN A, CARO EA, LAMPERTINI PML, BAINOTTI C, FORNICA B, RODRÍGUEZ SM, TRUOL G (2013). El complejo Acheria tosichella Keifer Wheat streak mosaic virus (WSMV) y High plains virus (HPV), situación en Argentina. Work. Coop. Int. Embrapa/INTA 7.

ALLISON R, JOHNSTON RE, DOUGHERTY WG (1986). The nucleotide sequence of the coding region of tobacco etch virus genomic RNA: evidence for the synthesis of a single polyprotein. $\mathrm{Vi}$ rology 154:9-20. (https://doi.org/10.1016/00426822(86)90425-3).

ANANDALAKSHMI R, PRUSS GJ, GE X, MARATHE $R$, MALLORY AC, SMITH TH, VANCE VB (1998). $A$ viral suppressor of gene silencing in plants. Proceedings of the National Academy of Sciences of the United States of America 95:13079-13084. (https://doi.org/10.1073/pnas.95.22.13079).

ANJOS JRN DOS, KITAJIMA EW, FORMIGA LCM, LIN MT, CAETANO V DA R (1987). Ocorrência do vírus do mosaico-em-faixa da cevada ("barley stripe mosaic virus") no Distrito Federal. Fitopatologia Brasileira 12:278-281.

ATABEKOV JGG, DOROKHOV YL (1984). Plant virus-specific transport function and resistance of plants to viruses. Academic Press.

ATREYA PL, ATREYA CD, PIRONE TP (1991). Amino acid substitutions in the coat protein result in loss of insect transmissibility of a plant virus. Proceedings of the National Academy of Sciences of the United States of America 88:7887-7891. (https://doi.org/10.1073/pnas.88.17.7887).

ATREYA PL, LOPEZ-MOYA JJ, CHU M, ATREYA CD, PIRONE TP (1995). Mutational analysis of the coat protein $\mathrm{N}$-terminal amino acids involved in potyvirus transmission by aphids. Journal of General Virology 76:265-270. (https://doi. org/10.1099/0022-1317-76-2-265).

BAINOTTI C, FORNICA B, HELGUERA M, VANZETTI L, FRASCHINA J, SALINES JH, ALBERIONE E, GÓMEZ D, DONAIRE G, PONTAROLI AC, ALEMANDRI VM, TRUOL G (2013). Mejoramiento de trigo para vírusência al Wheat streak mosaic vírus (WSMV) Hight plains vírus (HPV). Desarrollo y evaluación de germoplasma argentino y brasileño em infecciones naturales y artificiales. Work. Coop. Int. Embrapa/INTA 11-14.

BARBIERI RL, CARVALHO FIF DE, BARBOSA NETO JF, CAETANO V DA R, MARCHIORO VS, AZEVEDO R DE, LONRECETTI C (2001). Análise dialélica para tolerância ao vírus-do-nanismo-amarelo-da-cevada em cultivares brasileiras de trigo. Pesquisa Agropecuária Brasileira 36:131-135. (https://doi.org/10.1590/S0100204X2001000100016).

BARBOSA MM, GOULART LR, PRESTES AM, JULIATTI FC (2001). Genetic control of resistance to soilborne wheat mosaic virus in Brazilian 
cultivars of Triticum aestivum L . Thell . Euphytica 122:417-422. (https://doi.org/https://doi. org/10.1023/A:1012937116394).

BARKER H (1987). Invasion of non-phloem tissue in Nicotiana clevelandii by potato leafroll luteovirus is enhanced in plants also infected with potato $\mathrm{Y}$ potyvirus. Journal of General Virology 68:1223-1227.

BARR DJS (1979). Morphology and host range of Polymyxa graminis, Polymyxa betae, and Ligniera pilorum from Ontario and some other areas. Canadian Journal of Plant Pathology 1:85-94. (https://doi.org/10.1080/07060667909501468).

BILIBIO MI, SALVADORI JR, LAU D, FERNANDES JMC, PEREIRA PRV DA S (2021). Manejo de afídeos e nanismo-amarelo em trigo: eficácia em três safras. Passo Fundo, RS: Embrapa Trigo. Boletim de Pesquisa e Desenvolvimento online, 99. BOTELHO SRA, DUARTE MF, BARBOSA AV, LAU D, SANCHES MM, FERNANDES FR (2016). Interception of wheat mosaic virus (WMoV) in Brazil in maize seeds from the United States. Pesquisa Agropecuária Brasileira 51:688-691. (https:// doi.org/10.1590/S0100-204X2016000500034).

BOULILA M (2011). Positive selection, molecular recombination structure and phylogenetic reconstruction of members of the family Tombusviridae: Implication in virus taxonomy. Genetics and Molecular Biology 34:647-660. (https://doi. org/10.1590/S1415-47572011005000046).

BRAKKE MK (1971a). Soil-borne wheat mosaic virus. Descr. Plant Viruses $n^{\circ} 71$.

BRAKKE MK (1971b). Wheat streak mosaic virus. In: CMI/AAB (Ed.) Descriptions of Plant Viruses, N. 48. Association of Applied Biologists, Wellesbourne, UK.

BRAKKE MK, BALL EM, HSU YH, LANGENBERG WG (1987). Wheat streak mosaic virus cylindrical inclusion body protein. Journal of General Virology 68:281-287. (https://doi.org/https://doi. org/10.1099/0022-1317-68-2-281).

BRAMMER SP, SCAGLIUSI SMM, BONATO ALV, TORRES GAM, CONSOLI L; NHANI JUNIOR A (2011). Biotecnologia aplicada à cultura do trigo. In: Pires JLF, Vargas L, Cunha GR da (Eds.) Trigo no Brasil: bases para produção competitiva e sustentável. Passo Fundo, Embrapa Trigo. pp. 453-488.

BURROWS M, THOMAS C, MCROBERTS N, BOSTOCK RM, COOP L, STACK J (2016). Coordi- nation of diagnostic efforts in the great plains: wheat virus survey and modeling of disease onset. Plant Disease 100:1037-1045. (https://doi. org/10.1094/pdis-04-15-0467-fe).

CADLE-DAVIDSON L, BERGSTROM GC (2004). The effects of postplanting environment on the incidence of soilborne viral diseases in winter cereals. Phytopathology 94:527-534. (https://doi. org/10.1094/PHYTO.2004.94.5.527).

CADLE-DAVIDSON L, SORRELLS ME, GRAY SM, BERGSTROM GC (2006). Identification of small grains genotypes resistant to soilborne wheat mosaic virus. Plant Disease 90:1039-1044. (https://doi.org/10.1094/PD-90-1039).

CAETANO V DA R (1968). Nota prévia sobre a ocorrência de uma virose em cereais de inverno no Rio Grande do Sul. Revista da Sociedade Brasileira de Fitopatologia 2:53-66.

CAETANO V DA R (1982a). Vírus da espiga branca do trigo. In: Osório EA (ed) Trigo no Brasil. Campinas: Fundação Cargill, pp 570-573.

CAETANO V DA R (1998). O impacto das doenças do trigo transmitidas por vetores. Correio Agrícola 1:16-19

CAETANO V DA R (1982b). Mosaico do trigo transmitido pelo solo "wheat soilborne mosaic virus" Tobamovirus. In: Osório EA (ed) Trigo no Brasil, 2nd edn. Fundação Cargill, Campinas, pp 563570

CAETANO V DA R, KITAJIMA EW, COSTA AS (1978). Ocorrência e estudos electrono-microscópicos do vírus do mosaico do trigo, transmitido pelo solo, no estado do Rio Grande do Sul. Fitopatologia Brasileira 3:39-46.

CAETANO V DA R, KITAJIMA EW, COSTA AS (1970). Espiga branca do trigo, uma possível molestia de virus. Bragantia 29:XLI-XLIV.

CAETANO V DA R, MARINHO VLA, LIN MT, FORMIGA LCM, KITAJIMA EW (1990). Ocorrência do vírus do mosaico do capim bromo ("brome mosaic virus") em trigo, no estado do Rio Grande do Sul. Fitopatologia Brasileira 15:363-365.

CAETANO V DA R, PIEROBOM CR, LUZZARDI CG, PRESTES AM (1971). Mosaico do trigo começa a causar problema. In: Pesquisa Agropecuária Sul. DNPEA, Minist. Agric. p. 2.

CAMPBELL RN (1996). Fungal transmission of plant viruses. Annual Review of Phytopathology 34:87-108.

CARMINATTI AJ, MAR TB, LAU D, et al (2011). Ava- 
liação de métodos para diagnose de vírus que causam Mosaico em trigo no Brasil. VII Most. Iniciação Científica da Embrapa Trigo.

CARRINGTON JC, DOUGHERTY WG (1987a). Processing of the tobacco etch virus $49 \mathrm{~K}$ protease requires autoproteolysis. Virology 160:355-362. (https://doi.org/10.1016/0042-6822(87)900067).

CARRINGTON JC, DOUGHERTY WG (1987b). Small nuclear inclusion protein encoded by a plant potyvirus genome is a protease. Journal of $\mathrm{Vi}-$ rology 61:2540-2548. (https://doi.org/10.1128/ JVI.61.8.2540-2548.1987).

CARRINGTON JC, HERNDON KL (1992). Characterization of the potyviral HC-pro autoproteolytic cleavage site. Virology 187:308-315. (https:// doi.org/10.1016/0042-6822(92)90319-k).

CARRINGTON JC, JENSEN PE, SCHAAD MC (1998). Genetic evidence for an essential role for potyvirus $\mathrm{Cl}$ protein in cell-to-cell movement. The Plant Journal 14:393-400. (https://doi.org/10.1046/ j.1365-313x.1998.00120.x).

CASTIGLINI E, NAVIA D (2008). Prospección de Aceria tosichella em gramíneas de Uruguay. In: Workshop en virosis de cereales transmitidas por el ácaro Aceria tosichella -Wheat streak mosaic virus High plains virus- en los países del Cono Sur: situación, detección y manejo. In: Libro de Resúmenes. Argentina, pp. 25-26.

CEZARE DG DE, SCHONS J, LAU D (2011). Análise da resistência/tolerância da cultivar de trigo BRS Timbaúva ao Barley yellow dwarf virus-PAV. Tropical Plant Pathology 36:249-255. (https://doi. org/10.1590/S1982-56762011000400006).

CUNHA GR DA, PIRES JLF, VARGAS L (2011). Bases para produção competitiva e sustentável de trigo no Brasil. In: Pires JLF, Vargas L, Cunha GR da (Eds.) Trigo no Brasil: bases para produção competitiva e sustentável. Passo Fundo, Embrapa Trigo. pp. 19-26.

CHALHOUB BA, KELLY L, ROBAGLIA C, LAPIERRE HD (1994). Sequence variability in the genome-3'-terminal region of BYDV for 10 geographically distinct PAV-like isolates of barley yellow dwarf virus: analysis of the ORF6 variation. Archives of Virology 139:403-416.

CHARE ER, HOLMES EC (2006). A phylogenetic survey of recombination frequency in plant RNA viruses. Archives of Virology 151:933-946.

CHEN J, WILSON T (1995). Taxonomy of rigid rod- shaped viruses transmitted by fungi. Agronomy EDP Science 15:421-426. (https://doi. org/10.1051/agro:19950706).

CHIBA S, HLEIBIEH K, DELBIANCO A, KLEIN E, RATTI C, ZIEGLER-GRAFF V, BOUZOUBAA S, GILMER D (2013). The Benyvirus RNA silencing suppressor is essential for long-distance movement, requires both zinc-finger and nols basic residues but not a nucleolar localization for its silencing-suppression activity. Molecular Plant-Microbe Interactions 26:168-181. (https:// apsjournals.apsnet.org/doi/10.1094/MPMI-0612-0142-R).

CHIBA S, MIYANISHI M, ANDIKA IB, KONDO $\mathrm{H}$, TAMADA T (2008). Identification of amino acids of the beet necrotic yellow vein virus p25 protein required for induction of the resistance response in leaves of Beta vulgaris plants. Journal of General Virology 89:1314-1323. (https://doi. org/10.1099/vir.0.83624-0).

CHOI IR, HALL JS, HENRY M, ZHANG L, HEIN GL, FRENCH R, STENGER DC (2001). Contributions of genetic drift and negative selection on the evolution of three strains of wheat streak mosaic tritimovirus. Archives of Virology 146:619-628. (https://doi.org/10.1007/s007050170167).

CHOI IR, HORKEN KM, STENGER DC, FRENCH R (2002). Mapping of the P1 proteinase cleavage site in the polyprotein of Wheat streak mosaic virus (genus Tritimovirus). Journal of General Virology 83:443-450. (https://doi.org/10.1099/00221317-83-2-443).

CHOI IR, HORKEN KM, STENGER DC, FRENCH R (2005). An internal RNA element in the P3 cistron of Wheat streak mosaic virus revealed by synonymous mutations that affect both movement and replication. Journal of General Virology 86:2605-2614. (https://doi.org/10.1099/ vir.0.81081-0).

CHOI IR, STENGER DC, FRENCH R (2000). Multiple interactions among proteins encoded by the mite-transmitted wheat streak mosaic tritimovirus. Virology 267:185-198. (https://doi. org/10.1006/viro.1999.0117).

CHRISTIAN ML, WILLIS WG (1993). Survival of wheat streak mosaic virus in grass hosts in Kansas for wheat harvest to fall wheat emergence. Plant Disease 77:239-242.

CHUNG BY, MILLER WA, ATKINS JF, FIRTH AE (2008). An overlapping essential gene in the 
Potyviridae. Proceedings of the National Academy of Sciences of the United States of America 105:5897-5902. (https://doi.org/10.1073/ pnas.0800468105).

CIMMYT Brome Mosaic Virus (BMV). http://wheatdoctor.org/brome-mosaic-virus-bmv. Accessed 19 Aug 2021.

CONAB (2021). Conab - Série Histórica das Safras. https://www.conab.gov.br/info-agro/safras/serie-historica-das-safras. Accessed 26 Aug 2021.

COSTA AS, CAETANO V DA R, KITAJIMA EW, COSTA CL (1973). Transmissão da espiga branca por cigarrinhas (Sogatella). In: $6^{\circ}$ Reunião Anual da Sociedade Brasileira de Fitopatologia. pp. 2.

COUTTS BA, HAMMOND NEB, KEHOE MA, JONES RAC (2008a). Finding Wheat streak mosaic virus in south-west Australia. Australian Journal of Agricultural Research 59:836-843.

COUTTS BA, STRICKLAND GR, KEHOE MA, et al (2008b). The epidemiology of Wheat streak mosaic virus in Australia: case histories, gradients, mite vectors, and alternative hosts. Australian Journal of Agricultural Research 59:844-853.

D'ARCY CJ (1995). Symptomatology and host range of barley yellow dwarf. In: D'arcy CJ, Burnett PA (eds) Barley Yellow Dwarf: 40 Years of Progress. APS Press, St. Paul, pp. 9-28.

Dalbosco M, Schons J, Prestes AM (2002a). Incidência e índice de doença do mosaico do trigo em cereais de inverno e em gramíneas de verão, associados ao Polymyxa graminis. Fitopatologia Brasileira 27:48-52. (https://doi.org/10.1590/ S0100-41582002000100007).

DALBOSCO $M$, SCHONS J, PRESTES AM, CECCHETTI D (2002b) Efeito do vírus do mosaico do trigo sobre o rendimento de trigo e triticale. Fitopatologia Brasileira 27:53-57. (https://doi. org/10.1590/S0100-41582002000100008).

DE MORI C (2016). Aspectos comerciais e econômicos do trigo. In: De Mori C, Antunes JM, Fae GS, Acosta A da S (eds) Trigo: o produtor pergunta, a Embrapa responde. Embrapa, Brasília, DF, pp. 297-309.

DE MORI C (2015). Aspectos econômicos da produção e utilização. In: Borém A, Scheeren PL (eds) Trigo: do plantio à colheita. Viçosa, MG, pp. 1134.

DE MIRANDA JR, MUÑOZ M, WU R, ESPINOZA AM (1996). Sequence of Echinochloa hoja blanca tenuivirus RNA-5. Virus Genes 1996122 12:131-
134. (https://doi.org/10.1007/BF00572951).

DEL ROSARIO MSE, SILL WHJR (1965). Physiological strains of Aceria tulipae and their relationship to the transmission of Wheat streak mosaic virus. Phytopathology 55:1168-1175.

DELFOSSE P, REDDY AS, LEGRÈVE A, THIRUMALA DK, ABDURAHMAN MD, MARAITE H, REDDY DV (2000). Serological methods for detection of Polymyxa graminis, an obligate root parasite and vector of plant viruses. Phytopathology 90:537-545. (https://doi.org/10.1094/PHYTO.2000.90.5.537).

DESLANDES JA (1949). Doenças de vírus em cereais em Pelotas. Agros 2:88-92.

DOLJA V V, HALDEMAN R, ROBERTSON NL, DOUGHERTY WG, CARRINGTON JC (1994). Distinct functions of capsid protein in assembly and movement of tobacco etch potyvirus in plants. EMBO Journal 13:1482-1491.

DOMIER LL (2012). Family Luteoviridae. Elsevier/ Academic Press, Oxford, UK.

DOMIER LL (1995). Genome structure and function of barley yellow dwarf viruses. In: D'arcy CJ, Burnett PA (eds) Barley Yellow Dwarf 40 Years of Progress. APS Press, St. Paul, pp. 181-201.

DOMIER LL, FRANKLIN KM, SHAHABUDDIN M, HELLMANN GM, OVERMEYER JH, HIREMATH ST, SIAW MF, LOMONOSSOFF GP, SHAW JG, RHOADS RE (1986). The nucleotide sequence of tobacco vein mottling virus RNA. Nucleic Acids Research 14:5417-5430. (https://doi. org/10.1093/nar/14.13.5417).

DOMIER LL, MCCOPPIN NK, LARSEN RC, D'ARCY CJ (2002). Nucleotide sequence shows that Bean leafroll virus has a Luteovirus-like genome organization. Journal of General Virology 83:1791-1798. (https://doi.org/https://doi. org/10.1099/0022-1317-83-7-1791).

DOUGHERTY WG, CARRINGTON JC (1988). Expression and function of potyviral gene products. Annual Review of Phytopathology 26:123-143. (https://doi.org/10.1146/annurev. py.26.090188.001011).

DOUGHERTY WG, SEMLER BL (1993). Expression of virus-encoded proteinases: functional and structural similarities with cellular enzymes. Microbiological Reviews 57:781-822. (https://doi. org/10.1128/mr.57.4.781-822.1993).

DRISKEL BA, DOSS P, LITTLEFIELD LJ, WALKER NR, VERCHOT-LUBICZ J (2004). Soilborne 
wheat mosaic virus movement protein and RNA and Wheat spindle streak mosaic virus coat protein accumulate inside resting spores of their vector, Polymyxa graminis. Molecular Plant-Microbe Interactions 17:739-748. (https://doi. org/10.1094/MPMI.2004.17.7.739).

DWYER GI, GIBBS MJ, GIBBS AJ, JONES RAC (2007). Wheat streak mosaic virus in Australia: relationship to isolates from the pacific northwest of the USA and its dispersion via seed transmission. Plant Disease 91:164-170. (https://doi. org/10.1094/pdis-91-2-0164).

EDWARDS MC, MCMULLEN MP (1988). Variation in tolerance to wheat streak mosaic virus among cultivars of hard red spring wheat. Plant Disease 72:705-707.

ELLIS MH, REBETZKE GJ, MAGO R, CHU P (2003). First report of Wheat streak mosaic virus in Australia. Australasian Plant Pathology 32:551-553. (https://doi.org/10.1071/AP03054).

ELLIS MH, REBETZKE GJ, KELMAN WM, MOORE CS, HYLES JE (2004). Detection of Wheat streak mosaic virus in four pasture grass species in Australia. Plant Pathology 53:239. (https:// doi.org/https://doi.org/10.1111/j.00320862.2004.00960.x).

ESQUIVEL-FARIÑA A, CAMELO-GARCÍA VM, KITAJIMA EW, REZENDE JAM, GONZÁLEZ-SEGNANA LR (2019). First report of wheat stripe mosaic virus in Paraguay. Australasian Plant Disease Notes 14:24. (https://doi.org/10.1007/ s13314-019-0355-4).

FAJARDO TVM, NICKEL O (2014). Simultaneous detection of four viruses affecting apple and pear by molecular hybridization using a polyprobe. Ciência Rural 44:1711-1714. (https://doi. org/10.1590/0103-8478CR20131629).

FALK BW, TSAI JK (1998). Biology and molecular biology of viruses in the genus Tenuivirus. Annual Review of Phytopathology 36:139-163. (https:// doi.org/10.1146/ANNUREV.PHYTO.36.1.139).

FARGETTE D, PINEL-GALZI A, SÉRÉMÉ D, LACOMBE S, HÉBRARD E, TRAORÉ O, KONATÉ G (2008). Diversification of Rice yellow mottle yirus and related viruses spans the history of agriculture from the neolithic to the present. PLOS Pathogens 4:e1000125. (https://doi.org/10.1371/ JOURNAL.PPAT.1000125).

FELLOWS H, SILL WHJR (1955). Predicting Wheat streak mosaic epiphytotics in winter wheat.
Plant Disase Reporter, 39:291-295.

FERNÁNDEZ A, GUO HS, SÁENZ P, SIMÓN-BUELA L, GÓMEZ DE CEDRÓN M, GARCÍA JA (1997). The motif $\mathrm{V}$ of plum pox potyvirus $\mathrm{CI}$ RNA helicase is involved in NTP hydrolysis and is essential for virus RNA replication. Nucleic Acids Research 25:4474-4480. (https://doi.org/10.1093/ nar/25.22.4474).

FERNÁNDEZ A, LAÍN S, GARCÍA JA (1995). RNA helicase activity of the plum pox potyvirus $\mathrm{Cl}$ protein expressed in Escherichia coli. Mapping of an RNA binding domain. Nucleic Acids Research 23:1327-1332. (https://doi.org/10.1093/ nar/23.8.1327).

FIGUEROA M, HAMMOND-KOSACK KE, SOLOMON PS (2018). A review of wheat diseases-a field perspective. Molecular Plant Pathology 19:1523-1536. (https://doi.org/10.1111/ mpp.12618).

FONTANELI RS, DEL DUCA L DE J, SANTOS HP DOS, FONTANELI RS, CAIERÃO E (2011). Trigo de duplo propósito. In: Pires JLF, Vargas L, Cunha GR da (Eds.) Trigo no Brasil: bases para produção competitiva e sustentável. Passo Fundo, Embrapa Trigo. pp. 239-252.

FRENCH R, STENGER DC (2003). Evolution of Wheat streak mosaic virus: dynamics of population growth within plants may explain limited variation. Annual Review of Phytopathology 41:199-214. (https://doi.org/10.1146/annurev. phyto.41.052002.095559).

FRITZSCHE R (1975). Übertragung des Trespenmosaik- und Arabis-Mosaik-Virus durch Nematoden in Abhängigkeit von der Infektiosität der Wurzeln der Wirtspflanzen. Archives of Phytopathology and Plant Protection 11:197-201. (https://doi.or g/10.1080/03235407509431174).

GÁBORJÁNYI R, SZABOLCS J (1987). Brome mosaic virus transmission by cereal leaf beetle (Oulema melanopus, Coleoptera, Chrysomelidae). Cereal Research Communications 15:259-264.

GAL-ON A, ANTIGNUS Y, ROSNER A, RACCAH B (1992). A zucchini yellow mosaic virus coat protein gene mutation restores aphid transmissibility but has no effect on multiplication. Journal of General Virology 73:2183-2187. (https://doi. org/10.1099/0022-1317-73-9-2183).

GILMER D, RATTI C (2017). ICTV Virus Taxonomy Profile: Benyviridae. Journal of General Virology 98:1571-1572. (https://doi.org/10.1099/ 
jgv.0.000864).

GOMES EP, SOUSA CNA DE, GUARIENTI EM, MOREIRA JCS, DEL DUCA L DE JA, SCHEEREN PL (1994). EMBRAPA 16: uma nova opção para os triticultores do Rio Grande do Sul e de Santa Catarina. Passo Fundo: EMBRAPA-CNPT, p. 14.

GRAY S, GILDOW FE (2003). Luteovirus-aphid interactions. Annual Review of Phytopathology 41:539-566.

Hadi BAR, Langham MAC, Osborne L, Tilmon KJ (2011) Wheat streak mosaic virus on wheat: biology and management. Journal of Integrated Pest Management 2:1-5.

HALL GS, LITTLE DP (2013). Within-host competition between barley yellow dwarf-PAV and -PAS. Virus Research 174:148-151. (https://doi.org/ https://doi.org/10.1016/j.virusres.2013.03.013).

HILL JH, MARTINSON CA, RUSSELL WA (1974). Seed transmission of Maize dwarf mosaic and Wheat streak mosaic viruses in maize and response of inbred lines 1 . Crop Science 14:232235

HIMMEL PT, SIMMONS FW, HEWINGS AD, GLAWE DA (1992). Effects of soil water status on infection of soft red winter wheat by soilborne wheat mosaic virus. Canadian Journal of Plant Pathology 14:147-151. (https://doi.org/10.1080/07060 669209500891).

HUNGER RM, SHERWOOD JL, EVANS CK, MONTANA JR (1992). Effects of planting date and inoculation date on severity of wheat streak mosaic in hard red winter wheat cultivars. Plant Disease 76:1056-1060.

INTERNATIONAL COMMITTEE ON TAXONOMY OF VIRUSES - ICTV (2021). ICTV 9th Report. Avaible at: https://talk.ictvonline.org/ictv-reports/ictv_9th_report/negative-sense-rna-viruses-2011/w/negrna_viruses/215/tenuivirus. Accessed on June 28, 2021.

INOUYE T (1996). Wheat yellow mosaic bymovirus. Viruses plants Descr List from VIDE Database Eds AA Brunt, K Cradtree, MJ Dallwitz, AJ Gibbs, L Watson Cent Agric Biosci Int Wallingford, Oxon 1388-1390.

JIANG W, GARRETT KA, PETERSON DE, HARVEY TL, BOWDEN RL, FANG L (2005). The window of risk for emigration of Wheat streak mosaic virus varies with host eradication method. Plant Disease 89:853-858. (https://doi.org/10.1094/PD89-0853).
JIAPING C (1993). Occurrence of fungally transmitted wheat mosaic viruses in China. Annals of Applied Biology 123:55-61. (https://doi. org/10.1111/J.1744-7348.1993.TB04072.X).

JONES RAC, COUTTS BA, MACKIE AE, DWYER GI (2005). Seed transmission of Wheat streak mosaic virus shown unequivocally in wheat. Plant Disease 89:1048-1050. ( https://doi.org/10.1094/ PD-89-1048).

JONES RAC, NAIDU RA (2019). Global dimensions of plant virus diseases: current status and future perspectives. Annual Review of Virology 6:1-23. (https://doi.org/10.1146/annurev-virology-092818-015606).

JORCELINO TM, GUIMARÃES GC, GELETE TB, ARAÚJO GLT, NORONHA PA, BENITO NP, SANCHEZ MM, SILVA MS (2019). Barley stripe mosaic virus-BSMV: Interception of quarantine virus absent in Brazil detected in imported barley germplasm. In: Congresso Brasileiro de Fitopatologia, 51. Sociedade Brasileira de Fitopatologia, Resumos... Recife, PE, p. 831.

KANYUKA K, WARD E, ADAMS MJ (2003). Polymyxa graminis and the cereal viruses it transmits: A research challenge. Molecular Plant Pathology 4:393-406. (https://doi.org/10.1046/j.13643703.2003.00177.x).

KAPOORIA RG, NDUNGURU J (2004). Occurrence of viruses in irrigated wheat in Zambia. EPPO Bulletin 34:413-419. (https://doi.org/10.1111/j. 1365-2338.2004.00771.x).

KITAJIMA EW, CAETANO V DA R, COSTA AS (1971). Inclusões intracelulares associadas à" espiga branca" do trigo. Bragantia 30:101-108.

KRUEGER EN, BECKETT RJ, GRAY SM, MILLER WA (2013). The complete nucleotide sequence of the genome of Barley yellow dwarf virus-RMV reveals it to be a new Polerovirus distantly related to other yellow dwarf viruses. Frontiers in Microbiology 4:205. (https://doi.org/10.3389/ fmicb.2013.00205).

KÜHNE T (2009). Soil-borne viruses affecting cereals-known for long but still a threat. Virus Research 141:174-183. (https://doi.org/10.1016/j. virusres.2008.05.019).

LANGENBERG WG (1993). Structural proteins of three viruses in the Potyviridae adhere only to their homologous cylindrical inclusions in mixed infections. Journal of Structural Biology 110:188195. (https://doi.org/10.1006/jsbi.1993.1021). 
LANOISELET VM, HIND-LANOISELET TL, MURRAY GM (2008). Studies on the seed transmission of Wheat streak mosaic virus. Australasian Plant Pathology 37:584-588. (https://doi.org/10.1071/ AP08059).

LAU D (2016). Sinal amarelo. Cultivar Grandes Culturas 17:36-39.

LAU D (2020). Manejo das viroses do trigo. A granja 39-40.

LAU D (2014). Trigo: viroses no ataque. Cultivar Grandes Culturas 185:32-36.

LAU D (2012). Monitoramento e diagnose do complexo Aceria tosichella e vírus transmitidos (Wheat streak mosaic virus, High plains virus) no Brasil e avaliação da resistência de cultivares para estimar o seu impacto na triticultura nacional. Passo Fundo, Embrapa Trigo (Relatório Técnico enviado ao CNPq/MAPA/SDA).

LAU D, MAR TB, CASTRO RL DE (2021a). Reação ao BYDV-PAV de cultivares de trigo do ensaio estadual do Rio Grande do Sul, em 2020. Comunicado Técnico 381.

LAU D, PEREIRA PRV D. S, CASTRO RL DE (2015). Reação cultivares de trigo ao mosaico comum - EECT/RS-2015. In: Reunião da Comissão Brasileira de Pesquisa de trigo e triticale. Comissão Brasileira de Pesquisa de Trigo e Triticale, Resumos... Londrina, PR, p 5.

LAU D, PEREIRA PRV DA S (2013). Reação de cultivares brasileiras de trigo ao Wheat streak mosaic virus. Work. Coop. Int. Embrapa/INTA 55-59.

LAU D, PEREIRA PRV DA S, CASTRO RL DE (2014a). Ensaio estadual de cultivares de trigo do Rio Grande do Sul 2013 - reação ao mosaico comum. Reunião da Comissão Brasileira de Pesquisa de trigo e triticale, 8.; Semin. Técnico do Trigo, 9., 2014, Canela; Reunião da Comissão Brasileira de Pesquisa de trigo e triticale, 9.; Semin. Técnico do Trigo, 10., 2015, Resumos... Passo Fundo, RS.

LAU D, PEREIRA PRV DA S, CASTRO RL DE (2014b).

Ensaio estadual de cultivares de trigo do Rio Grande do Sul 2014 - reação ao mosaico comum. Reunião da Comissão Brasileira de Pesquisa de trigo e triticale, 8.; Semin. Técnico do Trigo, 9., 2014, Canela; Reunião da Comissão Brasileira de Pesquisa de trigo e triticale, 9.; Semin. Técnico do Trigo, 10., 2015, Resumos... Passo Fundo, RS.

LAU D, PEREIRA PRV DA S, CASTRO RL DE, PEREIRA FS (2019). Ensaio estadual de cultivares de trigo do Rio Grande do Sul 2017 - reação ao
BYDV-PAV. In: Reunião da Comissão Brasileira de Pesquisa de trigo e triticale, 12. Melhoramento, Aptidão Industrial e Sementes. Resumos... Passo Fundo, RS, p. 497-501.

LAU D, PEREIRA PRV DA S, CASTRO RL DE, STEMPKOWSKI LA (2017). Ensaio estadual de cultivares de trigo do Rio Grande do Sul 2016 - reação ao BYDV-PAV. In: Fórum Nacional de Trigo. Reunião da Comissão Brasileira de Pesquisa de trigo e triticale, Resumos... Cascavel, PR. p. 211-215.

LAU D, SANTANA FM, MACIEL JLN, et al (2011). Doenças de trigo no Brasil. In: Pires JLF, Vargas L, Cunha GR da (eds) Trigo no Brasil: bases para produção competitiva e sustentável. Embrapa Trigo, Passo Fundo, pp. 283-324.

LAU D, STEMPKOWSKI LA, CASTRO RL DE (2021b). Caracterização da reação de cultivares de trigo do ensaio estadual do Rio Grande do Sul 2020 ao mosaico-comum. Passo Fundo, RS, Embrapa Trigo. Comunicado Técnico Online 384.

LAU D, SBALCHEIRO CC, MARTINS FC, SANTANA FM, MACIE JLN, FERNANDES JMC, COSTAMILAN L M, LIMA MIPM, KUHNEM P, CASA RT (2020). Principais doenças do trigo no sul do Brasil: diagnóstico e manejo. Passo Fundo, RS, Embrapa Trigo. Comunicado Técnico Online 375.

LAU D et al. (em preparação). Barley yellow dwarf virus no Brasil.

LAUFER $M$, MOHAMMAD $H$, MAISS $E$, RICHERT-PÖGGELER K, DALL'ARA M, RATTI C, GILMER D, LIEBE S, VARRELMANN M. (2018). Biological properties of Beet soil-borne mosaic virus and Beet necrotic yellow vein virus cDNA clones produced by isothermal in vitro recombination: Insights for reassortant appearance. Virology 518:25-33. (https://doi.org/10.1016/j. virol.2018.01.029).

LECOQ H, WIPF-SCHEIBEL C, VERDIN E, DESBIEZ $C$ (2018). Characterization of the first tenuivirus naturally infecting dicotyledonous plants. Archives of Virology 164:297-301. (https://doi. org/10.1007/S00705-018-4057-6).

LEDINGHAM GA (1939). Studies on Polymyxa graminis, N. Gen. N. SP., a Plasmodiophoraceous root parasite of wheat. Canadian Journal of Research 38-51. (https://doi.org/10.1139/cjr39c-005).

LEFKOWITZ EJ, DEMPSEY DM, HENDRICKSON RC, ORTON RJ, SIDDELL SG, SMITH DB (2018). Virus taxonomy: the database of the International Committee on Taxonomy of Viruses (ICTV). Nu- 
cleic Acids Research 46:708-717. (https://doi. org/10.1093/nar/gkx932).

LEGREVE A, DELFOSSE P, MARAITE H (2002). Phylogenetic analysis of Polymyxa species based on nuclear 5.8S and internal transcribed spacers ribosomal DNA sequences. Mycological Research 106:138-147.

LISTER RM, RANIERI R (1995). Distribution and economic importance of barley yellow dwarf. Barley yellow dwarf 40:29-53.

LIU Y, ZHAI H, ZHAO K, WU B, WANG X (2012). Two suppressors of RNA silencing encoded by cereal-infecting members of the family Luteoviridae. Journal of General Virology 93:18251830. (https://doi.org/https://doi.org/10.1099/ vir.0.042135-0).

LOMMEL SA (1986). Identification of Wheat spindle streak mosaic virus and its role in a new disease of winter wheat in Kansas. Plant Disease 70:964. (https://doi.org/10.1094/PD-70-964).

LÓPEZ-MOYA JJ, PIRONE TP (1998). Charge changes near the $\mathrm{N}$ terminus of the coat protein of two potyviruses affect virus movement. Journal of General Virology 79:161-165. (https://doi. org/10.1099/0022-1317-79-1-161).

MACIEL JLN, MORAES MG DE, ALMANÇA MAK, MATSUMURA ATS, FALCADE JH (2006). Ocorrência do vírus Rice stripe necrosis virus em lavouras de arroz do Rio Grande do Sul. Fitopatologia Brasileira 31:209. (https://doi.org/http://dx.doi. org/10.1590/S0100-41582006000200018).

MALMSTROM CM, HUGHES CC, NEWTON LA, STONER CJ (2005a). Virus infection in remnant native bunchgrasses from invaded California grasslands. New Phytologist 168:217-230. (https:// doi.org/10.1111/j.1469-8137.2005.01479.x).

MALMSTROM CM, MCCULLOUGH AJ, JOHNSON HA, NEWTON LA, BORER ET (2005b). Invasive annual grasses indirectly increase virus incidence in California native perennial bunchgrasses. Oecologia 145:153-164. (https://doi. org/10.1007/s00442-005-0099-z).

MALMSTROM CM, STONER CJ, BRANDENBURG S, NEWTON LA (2006). Virus infection and grazing exert counteracting influences on survivorship of native bunchgrass seedlings competing with invasive exotics. Journal of Ecology 94:264-275

MAR TB, LAU D, SCHONS J, PEREIRA PRV DA S, CARMINATTI, AJ (2013a). Identification and characterization of Wheat streak mosaic virus isolates in wheat-growing areas in Brazil. International Journal of Agronomy 2013:1-6. (https:// doi.org/10.1155/2013/983414).

MAR TB, LAU D, SCHONS J, et al (2013b). Molecular identification based on coat protein sequences of the Barley yellow dwarf virus from Brazil. Scientia Agricola 70:428-434. (https://doi. org/10.1590/S0103-90162013000600008).

MARINHO VL DE A, BATISTA M DE F, MILLER R (2004). Barley stripe mosaic virus praga quarentenária A1. Brasília, DF, Embrapa Recursos Genéticos e Biotecnologia. Comunicado Técnico 107.

MARTIN TJ (1978). Procedures for evaluating wheat streak mosaic virus resistance. Plant Disease 62:1062-1066.

MARTIN TJ, HARVEY TL, BENDER CG, SEIFERS DL (1984). Control of wheat streak mosaic virus with vector resistance in wheat. Phytopathology 74:963-964.

MASUMI M, IZADPANAH KA, JOUKAR L, KHERADNAM M (2001). Assessment of losses by wheat streak mosaic virus. Iranian Journal of Plant Pathology 37:221-232.

MCDONALD $M$, KENDALL A, BIAN W, MCCULLOUGH I, LIO E, HAVENS WM, GHABRIAL SA, STUBBS G (2010). Architecture of the potyviruses. Virology 405:309-313. (https://doi. org/10.1016/j.virol.2010.06.013).

MCELHANY P, REAL LA, POWER AG (1995). Vector Preference and Disease Dynamics: A Study of Barley Yellow Dwarf Virus. Ecology 76:444-457. (https://doi.org/10.2307/1941203).

MCKINNEY HH (1925). A mosaic disease of winter wheat and winter rye. U.S. Dept Agric Bull 1361:10.

MCKINNEY HH (1937). Mosaic diseases of wheat and related cereals. US Dep Agric Circ n 442.

MCKINNEY HH (1949). Virus isolates from mosaic wheat in the hard red winter wheat area. Plant Disease Report 33:346-349.

MCNEIL JE, FRENCH R, HEIN GL, BAENZINGER S, ESKRIDGE KM (1996). Characterization of genetic variability among natural populations of wheat streak mosaic virus. Phytopathology 86:1222-1227.

MERITS A, GUO D, JÄRVEKÜLG L, SAARMA M (1999). Biochemical and genetic evidence for interactions between potato A potyvirus-encoded proteins $\mathrm{P} 1$ and $\mathrm{P} 3$ and proteins of the putative replication complex. Virology 263:15-22. 
MILLER WA, LIU S, BECKETT R (2002). Barley yellow dwarf virus: Luteoviridae or Tombusviridae? Molecular Plant Pathology 3:177-183.

MILLER WA, RASOCHOVÁ L (1997). Barley yellow dwarf viruses. Annual Review of Phytopathology 35:167-190.

MORIONES E, ORTEGO F, RUIZ-TAPIADOR $M$, GUTIÉRREZ C, CASTAÑERA P, GARCIA-ARENAL $F$ (1993). Epidemiology of RPV- and PAVlike barley yellow dwarf viruses on winter barley in central Spain. Crop Protection 12:224-228. (https://doi.org/https://doi.org/10.1016/02612194(93)90113-W).

MURPHY JF, RHOADS RE, HUNT AG, SHAW JG (1990). The VPg of tobacco etch virus RNA is the 49-kDa proteinase or the N-terminal 24-kDa part of the proteinase. Virology 178:285-288. (https:// doi.org/10.1016/0042-6822(90)90405-g).

MYERS LD, SHERWOOD JL, SIEGERIST WC, HUNGER RM (1993). Temperature-influenced virus movement of resistance do Soil borne wheat mosaic virus in hard red winter wheat (Triticum aestivum). Phytopathology 83:548-551.

NAJAR A, HAMDI I, VARSANI A (2017). Barley yellow dwarf virus in barley crops in Tunisia: prevalence and molecular characterization. Phytopathologia Mediterranea 56:111-118. (https://doi. org/10.14601/Phytopathol_Mediterr-19308).

NAVIA D (2009). Ácaro Aceria tosichella Keifer e viroses transmitidas Wheat streak mosaic virus e High plain virus, uma nova ameaça aos cultivos de cereais na América do Sul - análise de risco de pragas, distribuição geográfica, hospedeiros, caracterização e controle. Embrapa Recursos Genéticos e Biotecnologia, Brasília.

NAVIA D, DE MENDONÇA RS, SKORACKA A, SZYDLO W, KNIHINICKI D, HEIN GL, PEREIRA PRV DA S, TRUOL G, LAU D (2013). Wheat curl mite, Aceria tosichella, and transmitted viruses: an expanding pest complex affecting cereal crops. Experimental and Applied Acarology 59:95-143. (https://doi.org/10.1007/s10493-012-9633-y).

NAVIA D, TRUOL G, MENDONCA RS, SAGADIN M (2006). Aceria tosichella Keifer (Acari: Eriophyidae) from Wheat streak mosaic virus-infected wheat plants in Argentina. International Journal of Acarology 32:189-193. (https://doi.org/10.10 80/01647950608684460).

NEUHAUSER S, BULMAN S, KIRCHMAIR M (2010). Plasmodiophorids: The challenge to understand soil-borne, obligate biotrophs with a multiphasic life cycle. In: Molecular Identification of Fungi. Springer Berlin Heidelberg, pp. 51-78.

Ni P, Vaughan RC, Tragesser B, Hoover $\mathrm{H}$, Kao CC (2014). The plant host can affect the encapsidation of Brome mosaic virus (BMV) RNA; BMV Virions Are Surprisingly Heterogeneous. Journal of Molecular Biology 426:1061. (https://doi. org/10.1016/J.JMB.2013.09.007).

NIBLETT CL, ZAGULA KR, CALVERT LA, STARK DM, SMITH CE, BEACHY RN, LOMMEL SA (1991). cDNA cloning and nucleotide sequence of the wheat streak mosaic virus capsid protein gene. Journal of General Virology 72:499-504. (https://doi.org/10.1099/0022-1317-72-3-499).

OLDFIELD GN (1970). Mite transmission of plant viruses. Annual Review of Entomology 15:343380.

OLDFIELD GN, PROESELER G (1996). Eriophyoid mites as vectors of plant pathogens. In: Lindquist EE, Sabelis MW, Bruin J (eds) Eriophyoid Mites: their Biology, Natural Enemies and Control. Elsevier Science, Amsterdam, pp. 259-275.

PAGAN I, HOLMES EC (2010). Long-term evolution of the Luteoviridae: time scale and mode of virus speciation. Journal of Virology 84:6177-6187. (https://doi.org/10.1128/jvi.02160-09).

PALLÁS V, SÁNCHEZ-NAVARRO JA, JAMES D (2018). Recent advances on the multiplex molecular detection of plant viruses and viroids. Frontiers in Microbiology 9:. (https://doi. org/10.3389/FMICB.2018.02087).

PARIZOTO G, REBONATTO A, SCHONS J, LAU D (2013). Barley yellow dwarf virus -PAV in Brazil : Seasonal fluctuation and biological characteristics. Tropical Plant Pathology 38:11-19. (https:// doi.org/10.1590/S1982-56762013000100002).

PARKER L, KENDALL A, BERGER PH, SHIEL PJ, STUBBS G (2005). Wheat streak mosaic virus-structural parameters for a Potyvirus. Virology 340:64-69. (https://doi.org/10.1016/j.virol.2005.06.022).

PEREIRA F, STEMPKOWSKI LA, FAJARDO TVM, NHANI JÚNIOR A, LAU D, MAR, TB, NASCIMENTO SC DO, BOGO A, CASA RT, SILVA FN DA (2022). A novel tenuivirus infecting wheat in Brazil. Archives of Virology (Aceito para publicação). PEREIRA PRV DA S, LAU D, MARSARO JÚNIOR AL (2016). Dinâmica populacional de afídeos vetores de BYDY: impactos ao rendimento de grãos 
em trigo. In: Reunião da Comissão Brasileira de Pesquisa de trigo e triticale. Anais... Londrina, PR., Londrina, pp 1-5.

PEREIRA PRV DA S, LAU D, NAVIA D (2013). Mapeamento da distribuição geográfica do ácaro-do-enrolamento-do-trigo Aceria tosichella Keifer (Prostigmata: Eriophyidae) no Brasil. Work. Coop. Int. EMBRAPA / INTA, 2013 Res. 8:29-32

PEREIRA PRV DA S, NAVIA D, SALVADORI JR, LAU D (2009). Occurrence of Aceria tosichella in Brazil. Pesquisa Agropecuária Brasileira 44:539-542. (https://doi.org/10.1590/S0100204X2009000500015).

PIEROBOM CR, LUZZARDI CG, CAETANO V DA R (1972). Ocorrência de Polymyxa graminis Led. em trigo no Rio Grande do Sul. In: Res. $5^{\circ}$ Cong. Soc. Bras. Fitopatologia. Resumos... Fortaleza, CE.

PRESTES AM, CAETANO V DA R, CAETANO V DA R, LINHARES AG, MEDEIROS MC, LANGER FA, DOTTO SR, ROSA OS, SOUSA CNA, GOMES E, SANTIAGO JC (1972). Levantamento da ocorrência de mosaico do trigo no Rio Grande do Sul em 1971. In: Res. $5^{\circ}$ Cong. Soc, Bras. Fitopatologia, Resumos...Fortaleza, CE.

REIS EM, CASA RT (2005). Danos causados por fungos associados a sementes de cereais de inverno. Summa Phytopathologica 31:138-140

REZENDE JAM, CAMELO VM, FLÔRES D, MELLO APOA, KITAJIMA EW, BEDENDO IP (2015). First Report of Beet necrotic yellow vein virus on Red Table Beet in Brazil. Plant Disease 99:423-423. (https://doi.org/10.1094/PDIS-10-14-1045PDN).

ROCHOW WF (1969). Biological properties of four isolates of barley yellow dwarf virus. Phytopathology 59:1580-1589.

ROJAS MR, ZERBINI FM, ALLISON RF, GILBERTSON RL, LUCAS WJ (1997). Capsid protein and helper component-proteinase function as potyvirus cell-to-cell movement proteins. Virology 237:283-295.

ROOSSINCK MJ, MARTIN DP, ROUMAGNAC P (2015). Plant virus metagenomics: advances in virus discovery. Phytopathology 105:716-727. (https://doi.org/10.1094/PHYTO-12-14-0356RVW).

ROSSI RM, NEVES MF (2004). Estratégias para o trigo no Brasil. Atlas, São Paulo, SP

RUBIES-AUTONELL C, VALLEGA V (1987). Observa- tions on a mixed Soil-borne wheat mosaic virus and Wheat spindle streak mosaic virus infection in durum wheat (Triticum durum Desf.). Journal of Phytopathology 119:111-121. (https://doi. org/10.1111/J.1439-0434.1987.TB00473.X).

RYBICKI EP, WECHMAR MB VON (1982). Characterisation of an aphid-transmitted virus disease of small grains. Journal of Phytopathology 103:306-322. (https://doi. org/10.1111/J.1439-0434.1982.TB01755.X).

SALM SN, REY ME, ROBERTSON NL, FRENCH R, RABENSTEIN F, SCHUBERT J (1996). Molecular cloning and nucleotide sequencing of the partial genomes of Agropyron and Hordeum mosaic viruses, two members of the Rymovirus genus in the taxonomic family Potyviridae. Archives of Virology 141:2115-2127. (https://doi. org/10.1007/bf01718219).

SALVADORI JR, TONET GEL (2001). Manejo integrado dos pulgões de trigo. Embrapa Trigo, Passo Fundo: EMBRAPA-CNPT.

SALVADORI JR, SALLES LAB (2002). Controle Biológicodos Pulgões do Trigo. In: Parra JRP, BoteIho PSM, Ferreira BSC, Bento JMS (Eds.) Controle Biológico no Brasil: parasitóides e predadores. São Paulo, SP. Manole. pp. 427-447.

SANCHES MM, MARTINS TP (2013). Desenvolvimento de métodos eficientes de detecção para WSMV e HPV para uso de estações quarentenárias. Work. Coop. Int. Embrapa/INTA 60-63.

SÁNCHEZ-SÁNCHEZ H, HENRY M, CÁRDENAS-SORIANO E, ALVIZO-VILLASANA HF (2001). Identification of Wheat streak mosaic virus and its vector Aceria tosichella in Mexico. Plant Disease 85:13-17.

SANTOS CDRD, SAMPAIO MV, LAU D, REDAELLI LR, JAHNKE SM, PIVATO J, CARVALHO FJ (2019). Taxonomic status and population oscillations of Aphidius colemani species group (Hymenoptera: Braconidae) in southern Brazil. Neotropical Entomolgy 2019486 48:983-991. (https://doi. org/10.1007/S13744-019-00716-2).

SAVARY S, DJURLE A, YUEN J, FICKE A, ROSSI V, ESKER PD, FERNANDES JMC, DEL PONTE EM, KUMAR J, MADDEN LV, PAUL P, MCROBERTS N, SINGH PK, HUBER L, POPE DE VALLAVIELLE C, SAINT-JEAN S, WILLOCQUET L (2017). A white paper on global wheat health based on scenario development and analysis. Phytopathology 107:1109-1122. (https://doi.org/10.1094/PHY- 
TO-01-17-0027-FI).

SAVARY S, WILLOCQUET L, PETHYBRIDGE SJ, ESKER P, MCROBERTS N, NELSON A (2019). The global burden of pathogens and pests on major food crops. Nature Ecology \& Evolution 3:430439. (https://doi.org/10.1038/s41559-0180793-y).

SCHEETS K, MILLER WA, SOMERA M (2020). Abolish the family Luteoviridae (Tolivirales) and move its 515 genera to the familes Tombusviridae (Tolivirales) and Solemoviridae (Sobelivirales). Avaible at: https://ictv.global/ictv/proposals/2020.026P.R.Abolish_Luteoviridae.zip. Accessed on December 15, 2021.

SCHONS J, OLIVEIRA C, TOLEDO KG (2011). Primeiro relato do Wheat spindle streak mosaic virus em plantas de trigo no Brasil. In: XLIV Congresso Brasileiro de Fitopatologia. Tropical Plant Pathology (Impresso). Lavras - MG: Sociedade Brasileira de Fitopatologia, Bento Gonçalves, pp. 1116-1116.

SEIFERS DL, MARTIN TJ (1988). Correlation of low level wheat streak mosaic virus resistance in Triumph 64 wheat with low virus titer. Phytopathology 78:703-707.

SERFLING A, KOPAHNKE D, HABEKUSS $A$, et al (2017). Wheat diseases: an overview. pp. 263294.

SHAH SJA, BASHIR M, MANZOOR N (2012) A review on Barley yellow dwarf virus. Crop Production for Agricultural Improvement 64:747-782. (https://doi.org/10.1007/978-94-007-41164_29).

SHAHABUDDIN M, SHAW JG, RHOADS RE (1988). Mapping of the tobacco vein mottling virus VPg cistron. Virology 163:635-637. (https://doi. org/10.1016/0042-6822(88)90307-8).

SHAHWAN IM, HILL JP (1984). Identification and occurrence of wheat streak mosaic virus in winter wheat in Colorado and its effects on several wheat cultivars. Plant Disease 68:579-581.

SIGNORET PA, ALLIOT B, POINSO B (1977). Présence en France du wheat spindle streak mosaic virus. Annales de Phytopathologie 9:377379.

SILVA MTB DA, COSTA EC, BALARDIN RS (2004). Reação de cultivares e eficiência do controle químico de pulgões vetores do Barley yellow dwarf virus em trigo. Ciência Rural 34:1333-1340. (https://doi.org/10.1590/S0103-
84782004000500003).

SIM T, WILLIS WG, EVERSMEYER MG (1988). Kansas plant disease survey. Plant Disease 72:832836.

SLYKHUIS JT (1976a). Virus and virus-like diseases of cereal crops. Annual Review of Phytopathology 14:189-210. (https://doi.org/10.1146/annurev.py.14.090176.001201).

SLYKHUIS JT (1976b). Wheat spindle streak mosaic virus. CMI/AAB Descriptions of Plant Viruses. Wellesbourne, UK: Association of Applied Biologists.

SLYKHUIS JT (1955). Aceria tulipae Keifer (Acarina: Eriophyidae) in relation to the spread of wheat streak mosaic. Phytopathology 45:116-128.

SLYKHUIS JT (1960). Evidence of soil-borne mosaic of wheat in Ontario. Canadian Plant Disease Survey $40: 1$.

SMIRNOVA E, FIRTH AE, MILLER WA, SCHEIDECKER D, BRAULT V, REINBOLD C, RAKOTONDRAFARA AM, CHUNG BYW, ZIEGLER-GRAFF V (2015). Discovery of a small non-AUG-initiated ORF in Poleroviruses and Luteoviruses that is required for long-distance movement. PLOS Pathogens 11:e1004868. (https://doi.org/10.1371/ journal.ppat.1004868).

SMITH VH, JONES TP, SMITH MS (2005). Host nutrition and infectious disease: An ecological view. Frontiers in Ecology and the Environment 3:268-274. (https://doi.org/10.1890/1540-9295 (2005)003[0268:HNAIDA]2.0.CO;2).

SÕMERA M, KVARNHEDEN A, DESBIEZ C, BLYSTAD D, SOOVÄLI P, KUNDU JK, GANTSOVSKI M, NYGREN J, LECOQ H, VERDIN E, SPETZ C, TAMISIER L, TRUVE E, MASSART S (2020). Sixty years after the first description: genome sequence and biological characterization of european Wheat striate mosaic virus infecting cereal crops. Phytopathology 110:68-79. (https://doi. org/10.1094/phyto-07-19-0258-fi).

SOMSEN HW, SILL WH (1970). The wheat curl mite, Aceria tulipae Keifer, in relation to epidemiology and control of wheat streak mosaic. Agricultural Experiment Station Research Publication, Kansas.

SOUZA R DE, SCHONS J, BRAMMER SP, PRESTES AP, SCHEEREN PL, NICOLINI-TEIXEIRA F, CECCHETTI D, LANZARINI AC (2005). Efeito do Soil-borne wheat mosaic virus sobre o metabolismo de cinco genótipos de trigo com diferentes 
níveis de resistência à doença. Fitopatologia Brasileira 30:2-5. (https://doi.org/10.1590/S010041582005000400010).

STEMPKOWSKI LA, PEREIRA FS, VALENTE JB, FARIAS M, LAU D, DALMAGO GA, SANTI A, MAR TB, KUHNEM P, CASA RT, BOGO A, SILVA FN DA (2020). Management of wheat stripe mosaic virus by crop rotation. European Journal of Plant Pathology 158:349-361. (https://doi. org/10.1007/s10658-020-02077-8).

STENGER DC, FRENCH R (2004). Functional replacement of Wheat streak mosaic virus HC-Pro with the corresponding cistron from a diverse array of viruses in the family Potyviridae. Virology 323:257-267. (https://doi.org/10.1016/j.virol.2004.03.014).

STENGER DC, FRENCH R (2009). Wheat streak mosaic virus genotypes introduced to Argentina are closely related to isolates from the American Pacific Northwest and Australia. Archives of Virology 154:331-336. (https://doi.org/10.1007/ s00705-008-0297-1).

STENGER DC, HALL JS, CHOI IR, FRENCH R (1998). Phylogenetic relationships within the family potyviridae: wheat streak mosaic virus and brome streak mosaic virus are not members of the genus rymovirus. Phytopathology 88:782-787. (https://doi.org/10.1094/phyto.1998.88.8.782).

STENGER DC, HEIN GL, FRENCH R (2006a). Nested deletion analysis of Wheat streak mosaic virus HC-Pro: Mapping of domains affecting polyprotein processing and eriophyid mite transmission. Virology 350:465-474. (https://doi. org/10.1016/j.virol.2006.02.015).

STENGER DC, HEIN GL, GILDOW FE, HORKEN KM, FRENCH R (2005). Plant virus HC-Pro is a determinant of eriophyid mite transmission. Journal of Virology 79:9054-9061. (https://doi. org/10.1128/jvi.79.14.9054-9061.2005).

STENGER DC, SEIFERS DL, FRENCH R (2002). Patterns of polymorphism in wheat streak mosaic virus: sequence space explored by a clade of closely related viral genotypes rivals that between the most divergent strains. Virology 302:58-70. (https://doi.org/10.1006/viro.2001.1569).

STENGER DC, YOUNG BA, FRENCH R (2006b). Random mutagenesis of wheat streak mosaic virus HC-Pro: non-infectious interfering mutations in a gene dispensable for systemic infection of plants. Journal of General Virology 87:2741-
2747. (https://doi.org/10.1099/vir.0.81933-0). STOETZER A, KAWAKAMI J, MARSARO JÚNIOR $A L$, LAU D, PEREIRA, PRV DA S, ANTONIAZZI N (2014). Protective effect and economic impact of insecticide application methods on barley. Pesquisa Agropecuária Brasileira 49:153-162. (https://doi.org/10.1590/S0100204X2014000300001).

STYER WE, NAULT LR (1996) Corn and grain plants. In: Lindquist EE, Sabelis MW, Bruin J (eds) Eriophyoid mites - their biology, natural enemies and control. The Netherlands, Elsevier Science B.V., Amsterdam, pp. 611-618.

SULLIVAN ML, AHLQUIST P (1997). cis-acting signals in Bromovirus RNA replication and gene expression: networking with viral proteins and host factors. Seminars in Virology 8:221-230. (https://doi.org/10.1006/SMVY.1997.0125).

TAMADA T, KONDO H (2013). Biological and genetic diversity of plasmodiophorid-transmitted viruses and their vectors. Journal of General Plant Pathology 79:307-320. (https://doi.org/10.1007/ s10327-013-0457-3).

TAMADA T, KUSUME T (1991). Evidence that the $75 \mathrm{~K}$ readthrough protein of beet necrotic yellow vein virus RNA-2 is essential for transmission by the fungus Polymyxa betae. Journal of General Virology 72:1497-1504.

TATINENI S, MCMECHAN AJ, WOSULA EN, WEGULO SN, GRAYBOSCH RA, FRENCH R, HEIN GL (2014). An eriophyid mite-transmitted plant virus contains eight genomic RNA segments with unusual heterogeneity in the nucleocapsid protein. Journal of Virology 88:11834-11845. (https://doi.org/10.1128/JVI.01901-14).

TATINENI S, VAN WINKLE DH, FRENCH R (2011). The $\mathrm{N}$-terminal region of wheat streak mosaic virus coat protein is a host- and strain-specific long-distance transport factor. Journal of Virology 85:1718-1731. (https://doi.org/10.1128/ jvi.02044-10).

TEREFE TG, VISSER B, BOTHA W, KOZANA A, ROBERTS R, THOMPSON GD, PRINSLOO G, READ DA (2020). Detection and molecular characterization of Wheat stripe mosaic virus on wheat in South Africa. Crop Protection 143:105464. (https://doi. org/10.1016/j.cropro.2020.105464).

THOMAS JA, HEIN GL (2003). Influence of volunteer wheat plant condition on movement of the wheat curl mite, Aceria tosichella, in win- 
ter wheat. Experimental \& Applied Acarology 31:253-268. (https://doi.org/10.1023/b:appa.0000010384.12678.46).

THOMAS JA, HEIN GL, LYON DJ (2004). Spread of wheat curl mite and Wheat streak mosaic virus is influenced by volunteer wheat control methods. Plant Health Progress 5:2. (https://doi. org/10.1094/PHP-2004-1206-01-RS).

TRUOL G, FRENCH R, SAGADIN M, ARNEODO $J$ (2004). First report of Wheat streak mosaic virus infecting wheat in Argentina. Australasian Plant Pathology 33:137-138. (https://doi. org/10.1071/ap03092).

TRUOL G, SAGADIN M (2007). Primera mención de la presencia de High Plains virus transmitido por Aceria tosichella Keifer (Acarina. Popstigmata) en trigos de Argentina. Fitopatologia Brasileira 32:249

URCUQUI-INCHIMA S, HAENNI AL, BERNARDI $F$ (2001). Potyvirus proteins: a wealth of functions. Virus Research 74:157-175. (https://doi. org/10.1016/s0168-1702(01)00220-9).

USDA (2021) Publication | Grain: World Markets and Trade | ID: zs25x844t | USDA Economics, Statistics and Market Information System. https:// usda.library.cornell.edu/concern/publications/ zs25x844t?locale=en. Accessed 10 Aug 2021

VALENTE JB, PEREIRA FS, STEMPKOWSKI LA, FARIAS $M$, KUHNEM P, LAU D, FAJARDO TVM, NHANI JUNIOR A, CASA RT, BOGO A, SILVA, FN DA (2019). A novel putative member of the family Benyviridae is associated with soilborne wheat mosaic disease in Brazil. Plant Pathology 68:588600. (https://doi.org/10.1111/ppa.12970).

VERCHOT J, CARRINGTON JC (1995). Evidence that the potyvirus $\mathrm{P} 1$ proteinase functions in trans as an accessory factor for genome amplification. Journal of Virology 69:3668-3674. (https://doi. org/10.1128/JVI.69.6.3668-3674.1995).

VERCHOT J, KOONIN E V, CARRINGTON JC (1991). The 35-kDa protein from the $\mathrm{N}$-terminus of the potyviral polyprotein functions as a third virus-encoded proteinase. Virology 185:527-535. (https://doi.org/10.1016/00426822(91)90522-d).

VIJAYAPALANI P, MAESHIMA $M$, NAGASAKI-TAKEKUCHI N, MILLER WA (2012). Interaction of the trans-frame potyvirus protein P3N-PIPO with host protein PCaP1 facilitates potyvirus movement. PLOS Pathogens 8:e1002639. (https://doi.org/10.1371/journal. ppat.1002639).

VRANDEČIĆ K, ĆOSIĆ J, NOVOSELOVIĆ D, STANKOVIC I, VUCUROVIC A, KRSTIC B, BULAJIC A (2015). First report of Wheat spindle streak mosaic virus on wheat in Croatia. Plant Disease 99:896. (https://doi.org/10.1094/PDIS-12-141288-PDN).

WANG H, WU K, LIU Y, WU Y, WANG X (2015). Integrative proteomics to understand the transmission mechanism of Barley yellow dwarf virus-GPV by its insect vector Rhopalosiphum padi. Scientific Reports 5:10971. (https://doi.org/10.1038/ srep10971https://www.nature.com/articles/ srep10971\#supplementary-information).

WARD E, ADAMS MJJ (1998). Analysis of ribosomal DNA sequences of Polymyxa species and related fungi and the development of genus- and species-specific PCR primers. Mycological Research 102:965-974. (https://doi.org/10.1017/ S0953756297005881).

WARD LI, FENN MGE, HENRY CM (2004). A rapid method for direct detection of Polymyxa DNA in soil. Plant Pathology 53:485-490. (https://doi.or g/10.1111/j.1365-3059.2004.01017).

WATERHOUSE PM, GILDOW FE, JOHNSTON GR (1988). Luteoviruses. 'Descriptions of Plant Viruses, No 339'Kew, Surrey, England, Commonw. Mycology Institute Association. Annals Applied Methods 132:172-180.

WIESE M V (1977). Compendium of wheat disease. The American Phytopathological Society 62-79.

WILLIAMS AS, PIRONE TP, SLYKHUIS JT, TUTT CR (1975). Wheat spindle streak mosaic virus in Kentucky. Plant Disease Report 59:888-889.

WU B, BLANCHARD-LETORT A, LIU Y, ZHOU G, WANG X, ELENA SF (2011). Dynamics of molecular evolution and phylogeography of Barley yellow dwarf virus-PAV. PLoS One 6:e16896. (https:// doi.org/10.1371/journal.pone.0016896).

WYLIE SJ, ADAMS M, CHALAM C, et al (2017). ICTV Virus Taxonomy Profile: Potyviridae. Journal of General Virology 98:352-354. (https://doi.org/ doi:10.1099/jgv.0.000740).

XIONG R, WU J, ZHOU Y, ZHOU X (2009). Characterization and subcellular localization of an RNA silencing suppressor encoded by Rice stripe tenuivirus. Virology 387:29-40. (https://doi. org/10.1016/J.VIROL.2009.01.045).

YOUNG BA, HEIN GL, FRENCH R, STENGER DC 
(2007). Substitution of conserved cysteine residues in wheat streak mosaic virus HC-Pro abolishes virus transmission by the wheat curl mite. Archives of Virology 152:2107-2111. (https:// doi.org/10.1007/s00705-007-1034-x).

YU W, XU Z, FRANCIS F, LIU Y, CHENG D, BRAGARD

C, CHEN J (2013). Variation in the transmission of barley yellow dwarf virus-PAV by different Sitobion avenae clones in China. Journal of Virological Methods 194:1-6. (https://doi.org/https://doi. org/10.1016/j.jviromet.2013.07.038).

ZAGULA KR, NIBLETT CL, ROBERTSON NL, FRENCH R, LOMMEL SA (1992). Potyviridae: genus Rymovirus. Potyvirus taxonomy 5:269-276. (https://doi.org/10.1007/978-3-7091-6920-
9_27).

ZHANG W, CHENG Z, XU L, WU M, WATERHOUSE P, ZHOU G, LI S (2009). The complete nucleotide sequence of the barley yellow dwarf GPV isolate from China shows that it is a new member of the genus Polerovirus. Archives of Virology 154:1125-1128. (https://doi.org/10.1007/ s00705-009-0415-8).

ZIEGLER A, KASTIRR U (2016). A new sequence variant of wheat spindle streak mosaic virus in Germany. Journal of Plant Diseases and Protection 123:133-135. (https://doi.org/10.1007/ S41348-016-0014-3). 